\title{
Synthesis of substituted 3(2H)-furanones Using Alkylative Intramolecular Cyclization of Sulfonium Salts
}

Sho Inagaki, ${ }^{\dagger}$ Mika Ukaku, ${ }^{\dagger}$ Akira Chiba, ${ }^{\dagger}$ Fumi Takahashi, ${ }^{\dagger}$ Yasuharu Yoshimi, ${ }^{\star}$ Toshio Morita ${ }^{\ddagger}$ and Tomikazu Kawano*,†

$\dagger$ Department of Medicinal and Organic Chemistry, School of Pharmacy, Iwate Medical University, Yahaba, Iwate 028-3694, Japan

* Department of Applied Chemistry and Biotechnology, Graduate School of Engineering, University of Fukui, 3-9-1 Bunkyo, Fukui 910-8507, Japan

\section{Contents}

${ }^{1} \mathrm{H}$ and ${ }^{13} \mathrm{C}$ NMR spectra.

4-Bromoacetoacetates 6

S2-S10

Sulfonium salts 1

S11-S19

5-Alkoxy-3(2H)-furanones 2

S20-S28

4-Alkylated 3(2H)-furanones 3

S29-S50

Aza-prostaglandin analogue $\mathbf{1 0}$

S51 


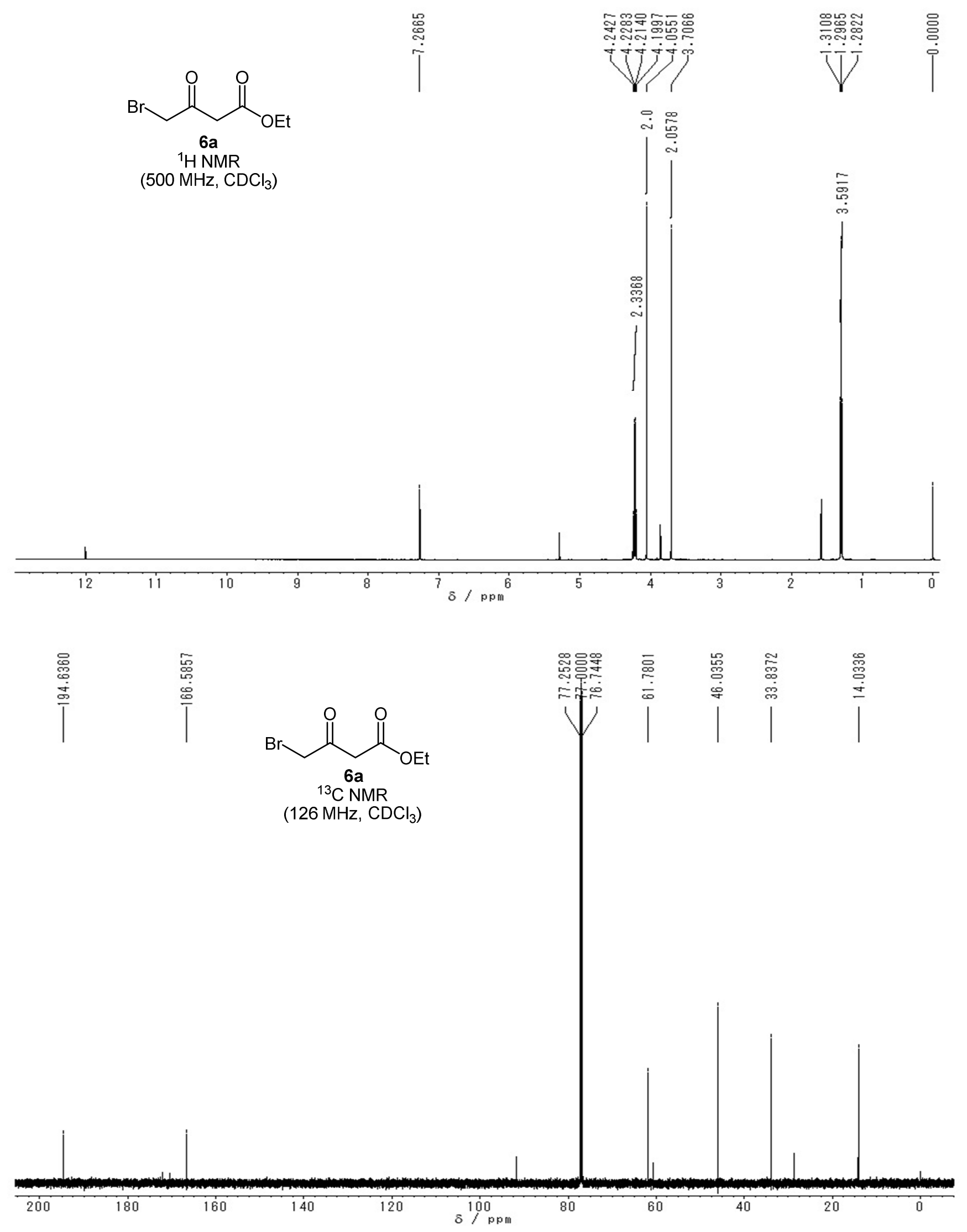


<smiles>CC(C)OC(=O)CC(=O)CBr</smiles>

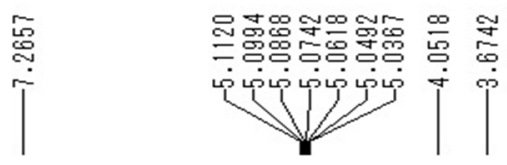

${ }^{1} \mathrm{H} N M R$

(500 MHz, CDCl 3 )

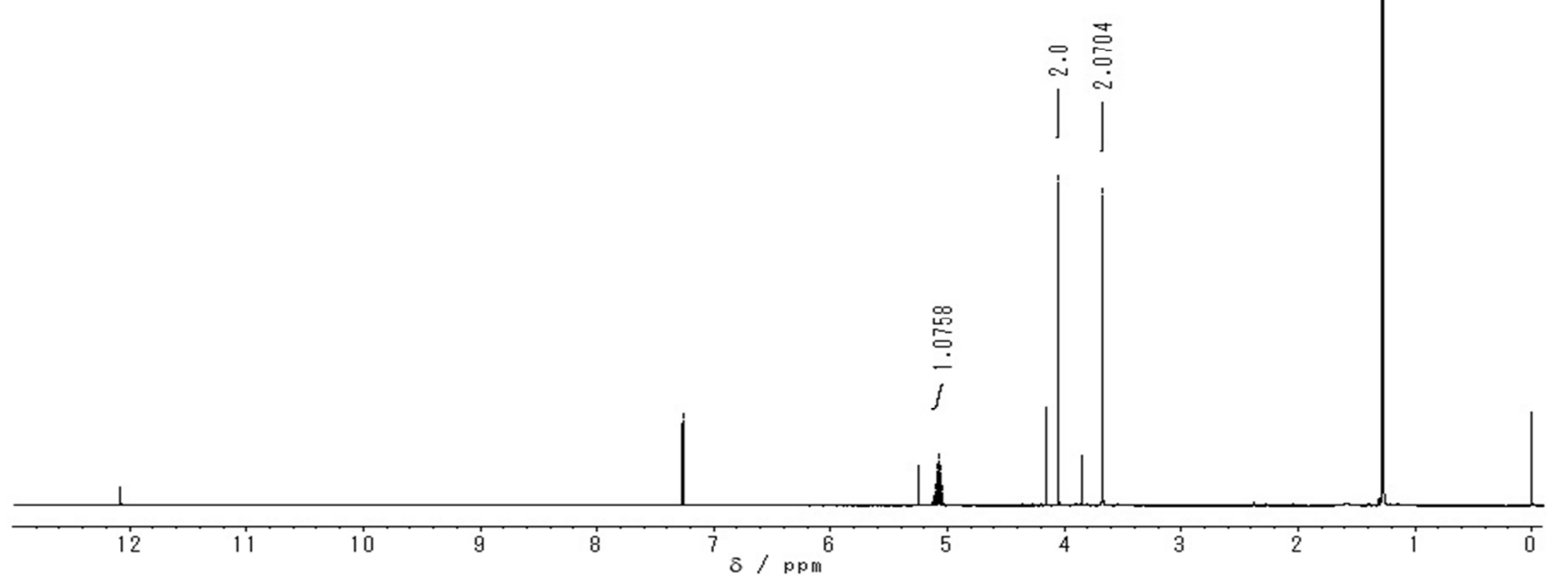

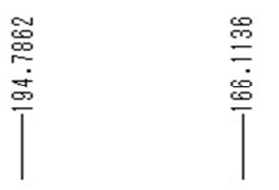<smiles>CC(C)OC(=O)CC(=O)CBr</smiles>

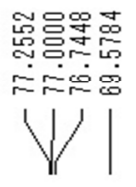

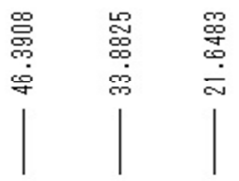

${ }^{13} \mathrm{C}$ NMR

$\left(126 \mathrm{MHz}, \mathrm{CDCl}_{3}\right.$ ) 


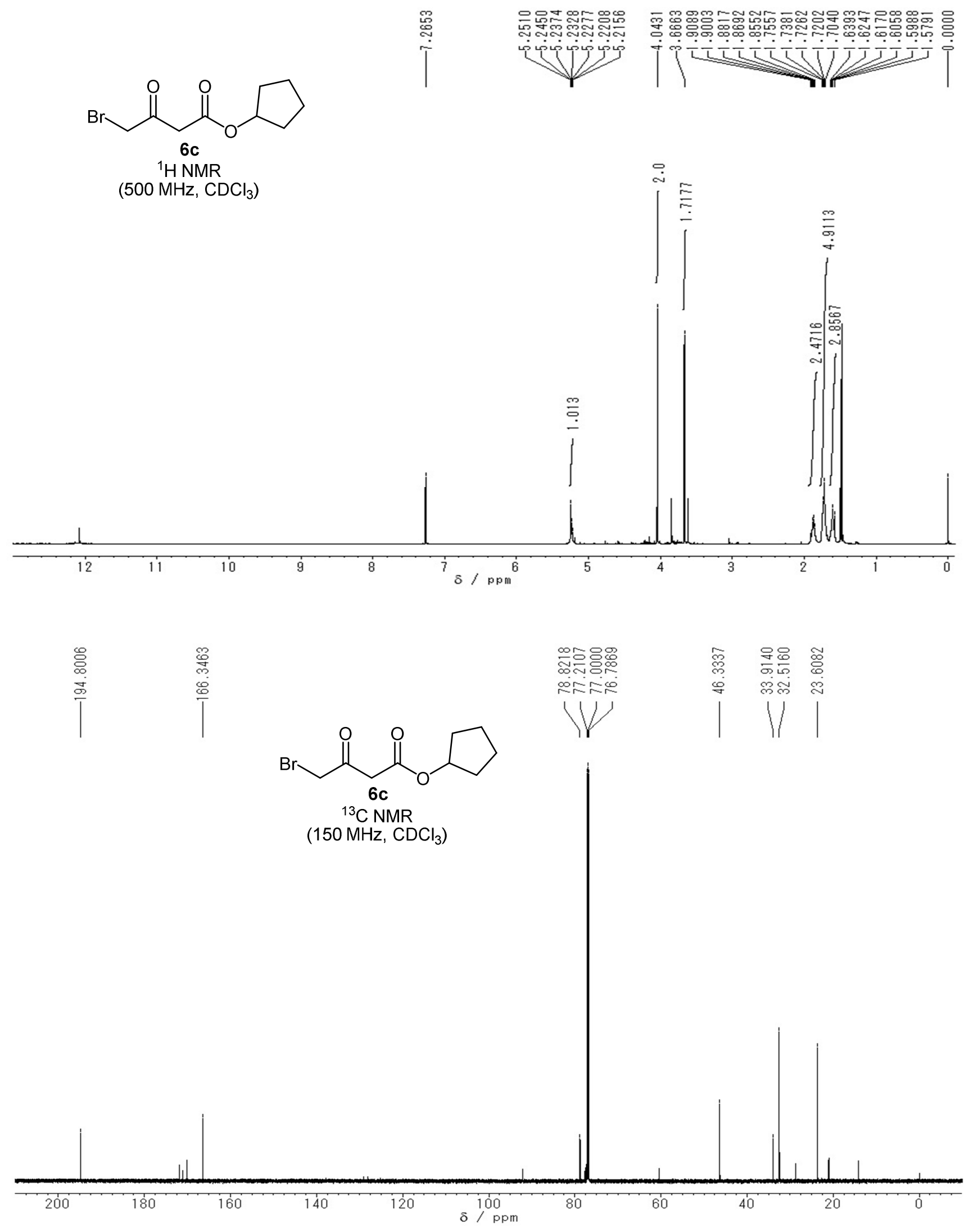




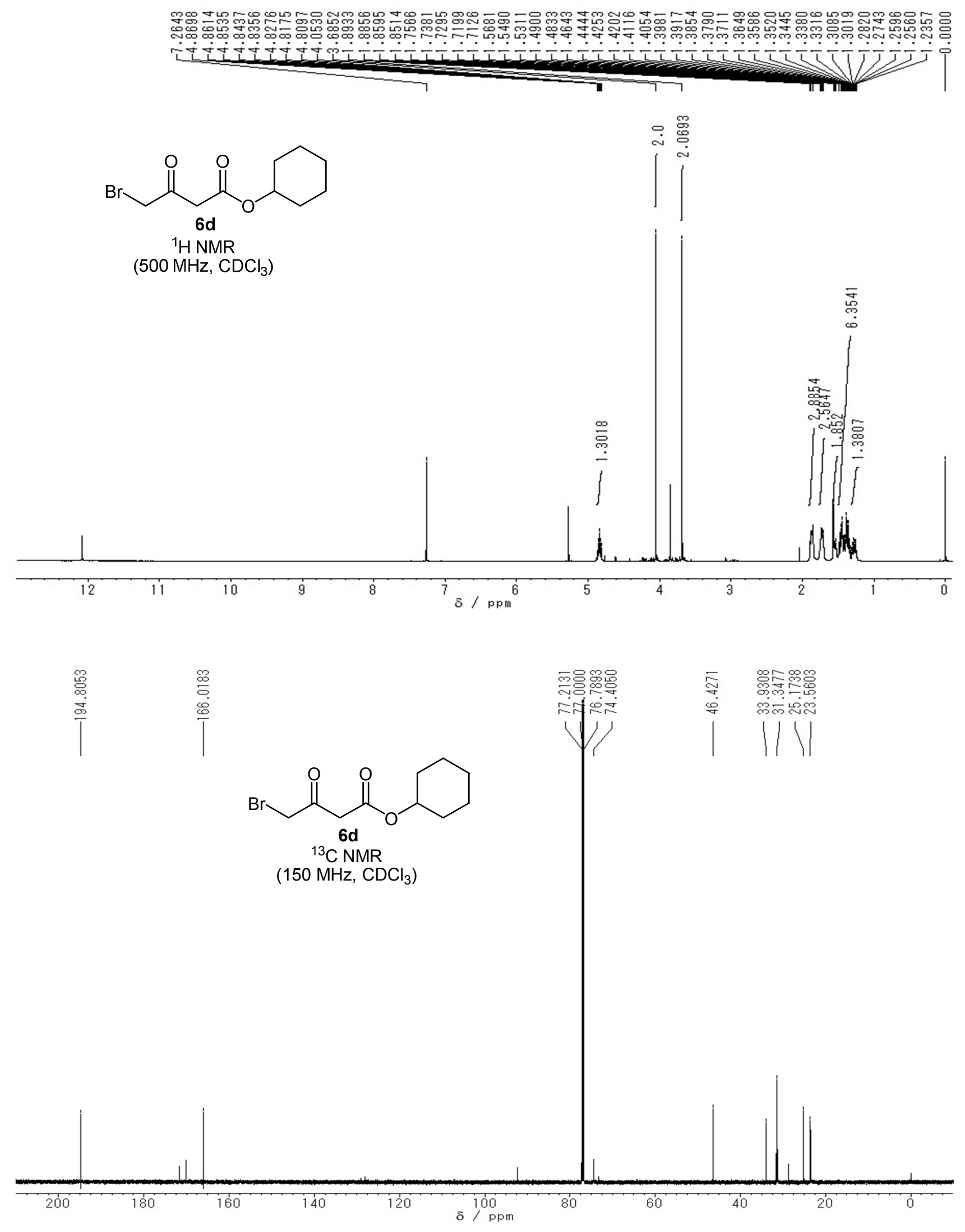



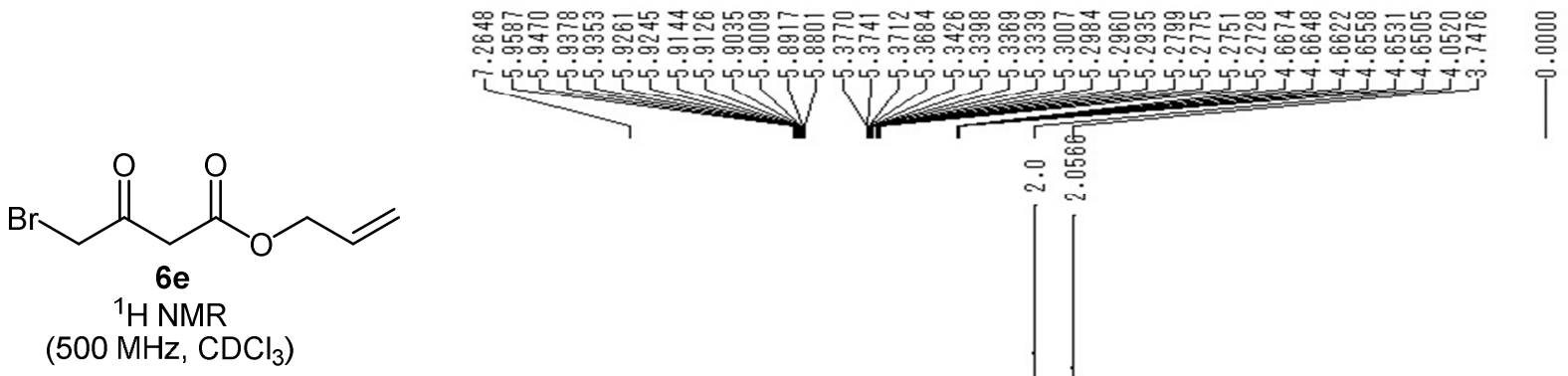

잉
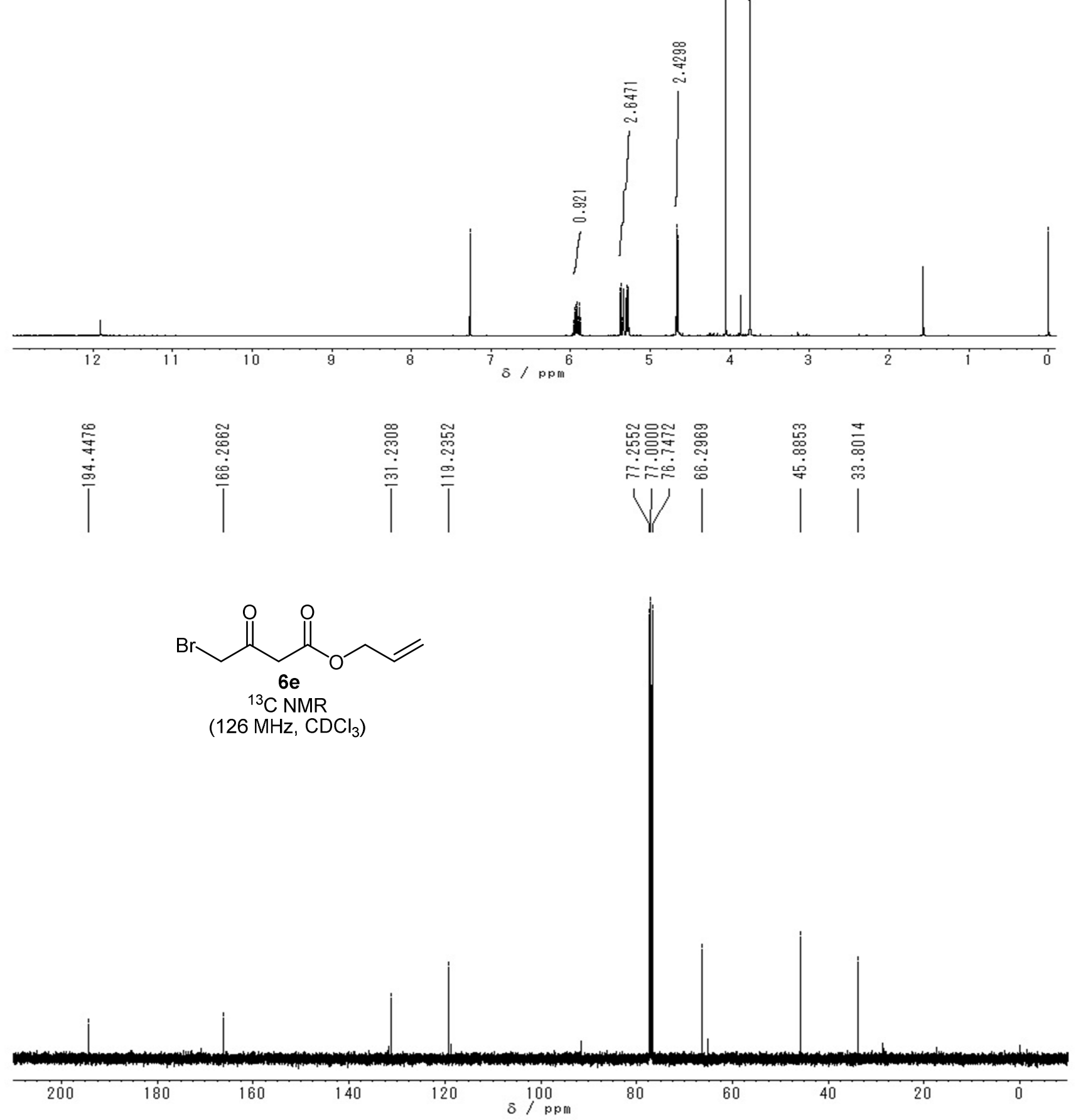


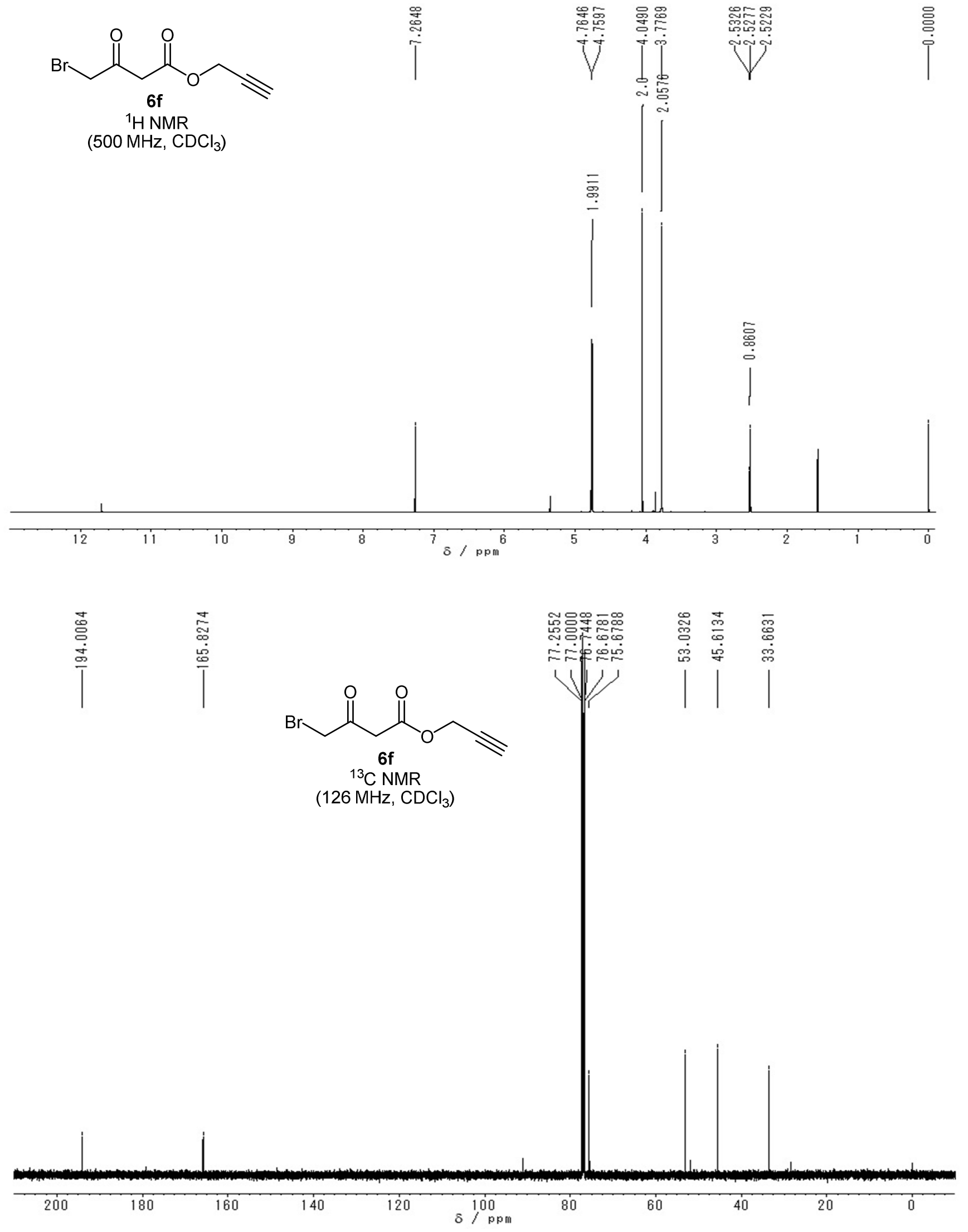



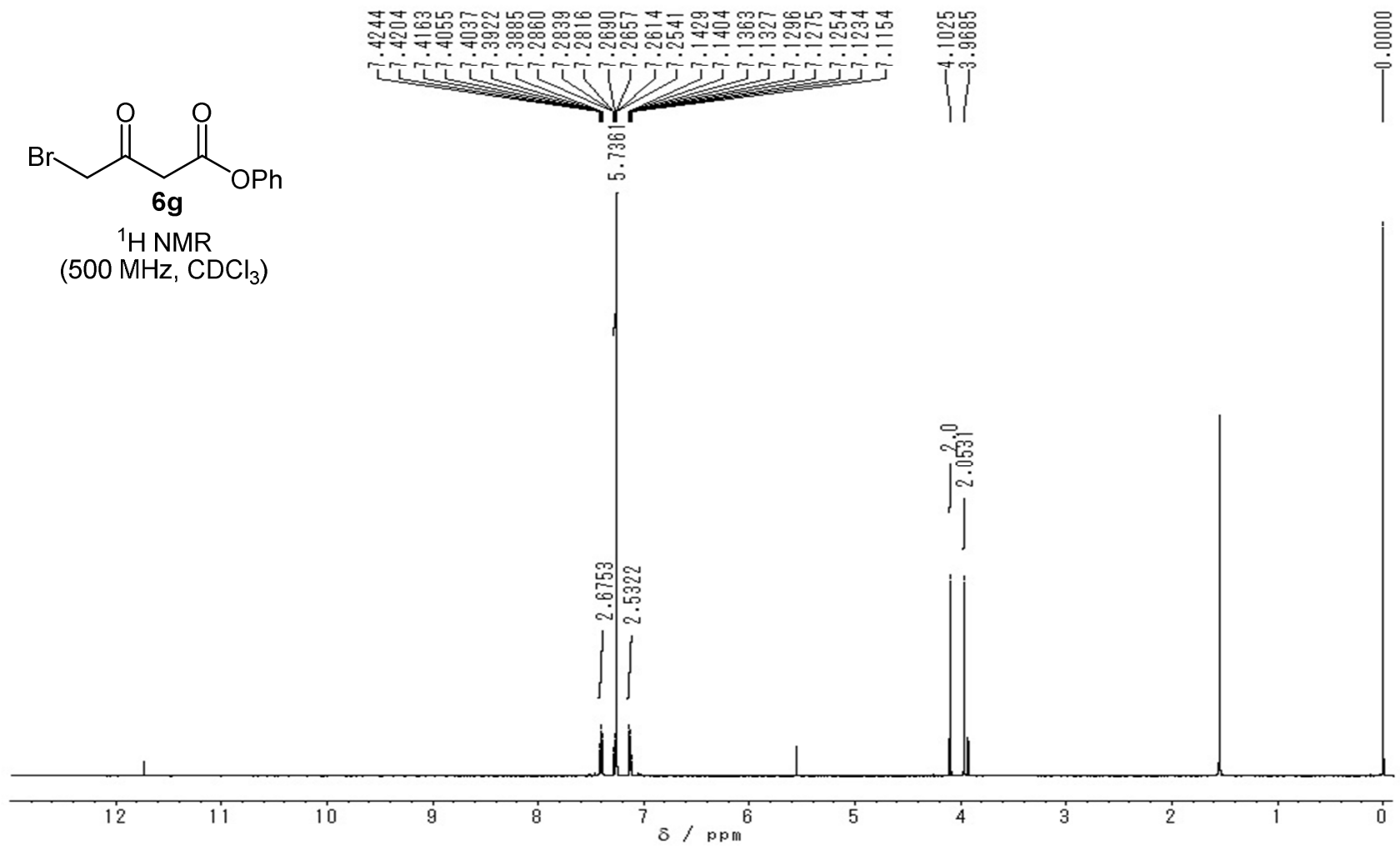

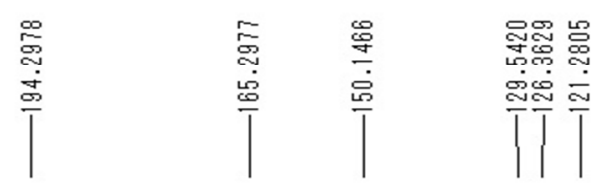
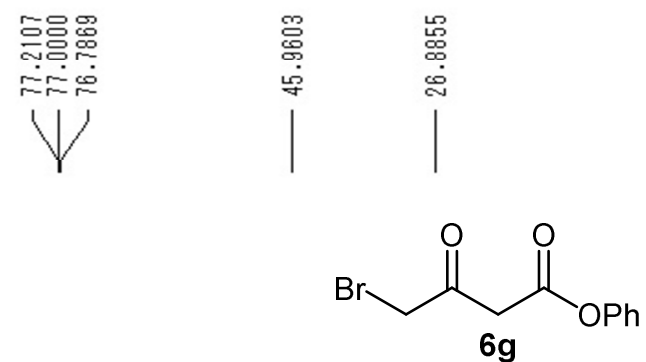

(150 MHz, $\left.\left.{ }^{{ }^{2} \mathrm{CDCl}}\right)_{3}\right)$

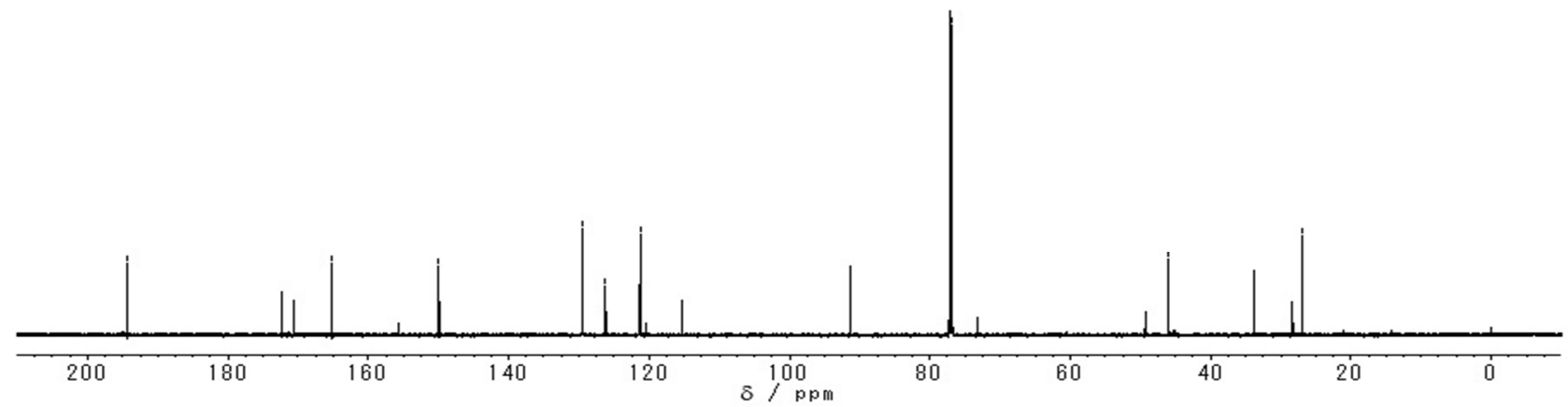




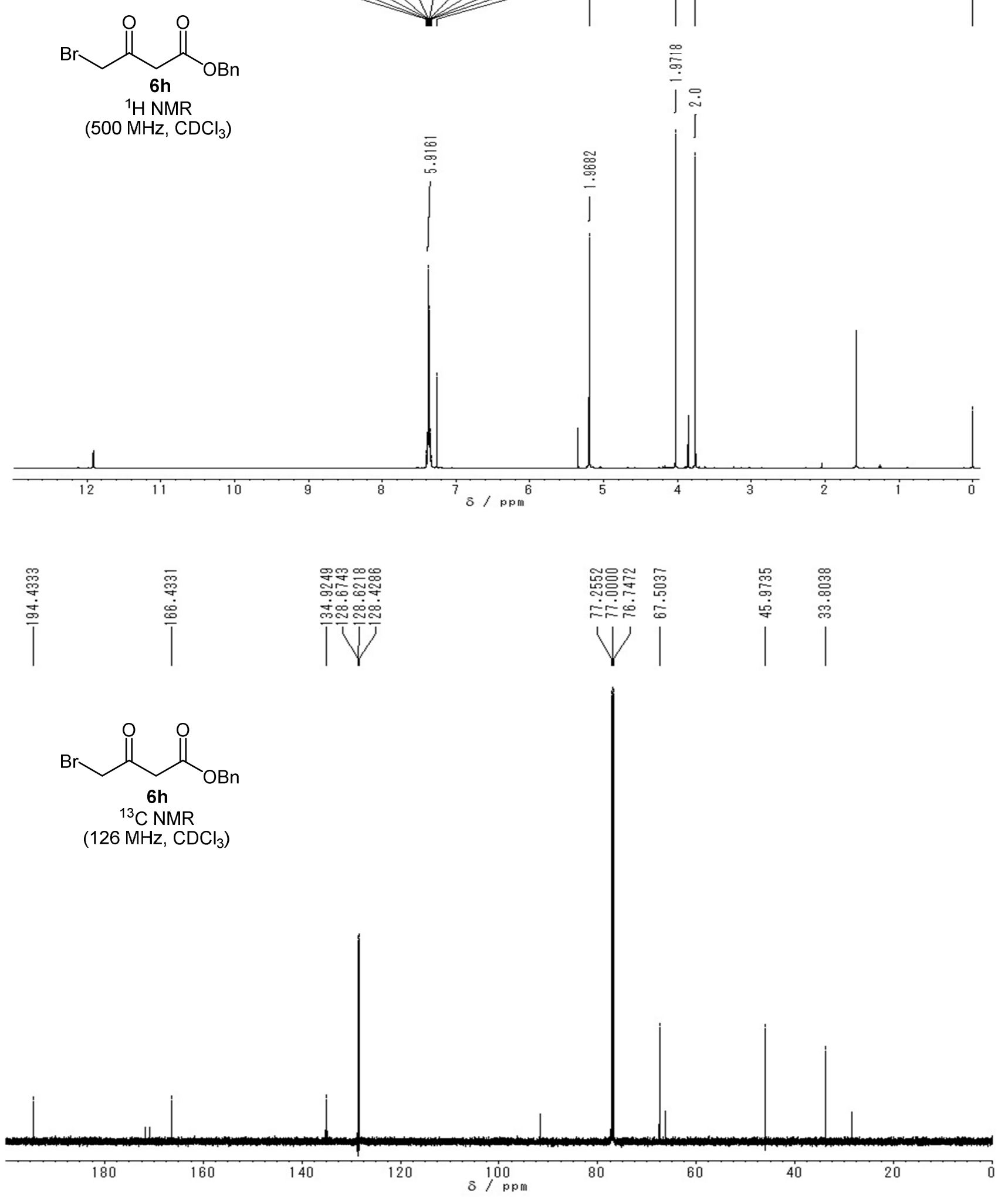




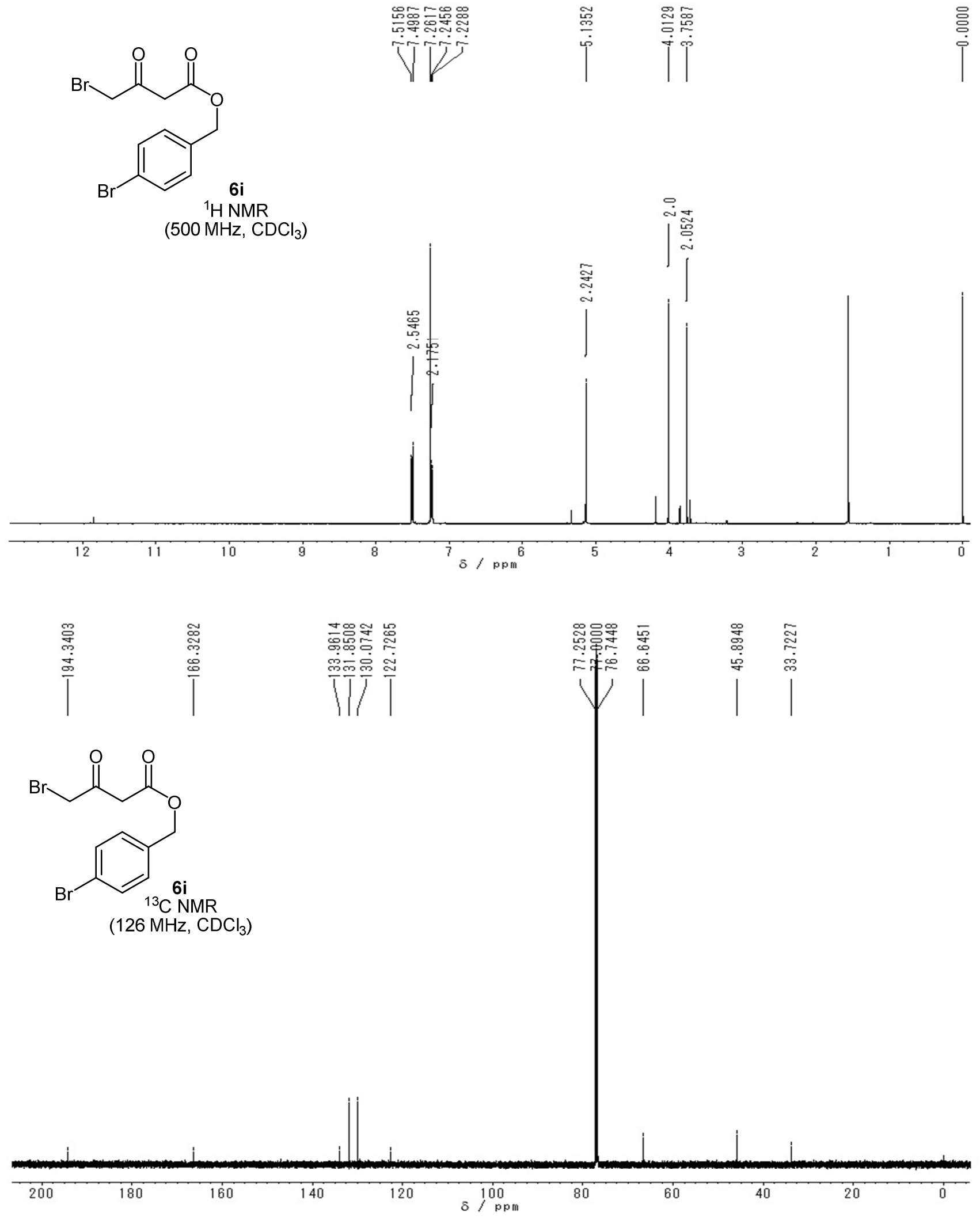



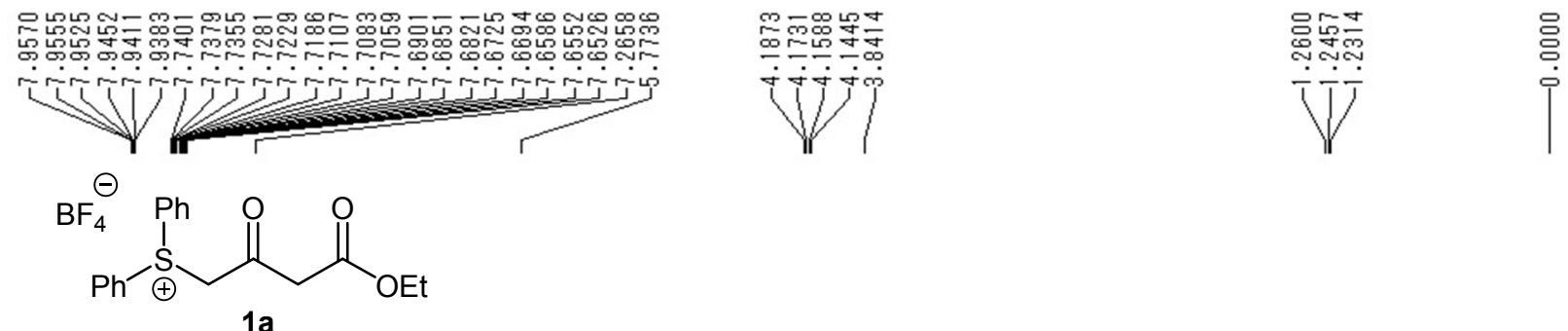

${ }^{1} \mathrm{H}$ NMR

(500 MHz, $\mathrm{CDCl}_{3}$ )

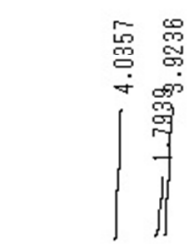

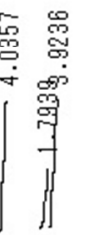

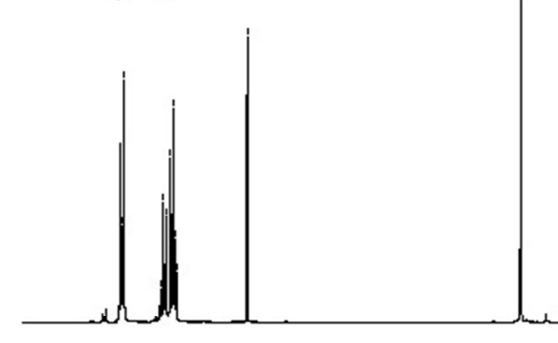

$\stackrel{\sim}{\circ}$
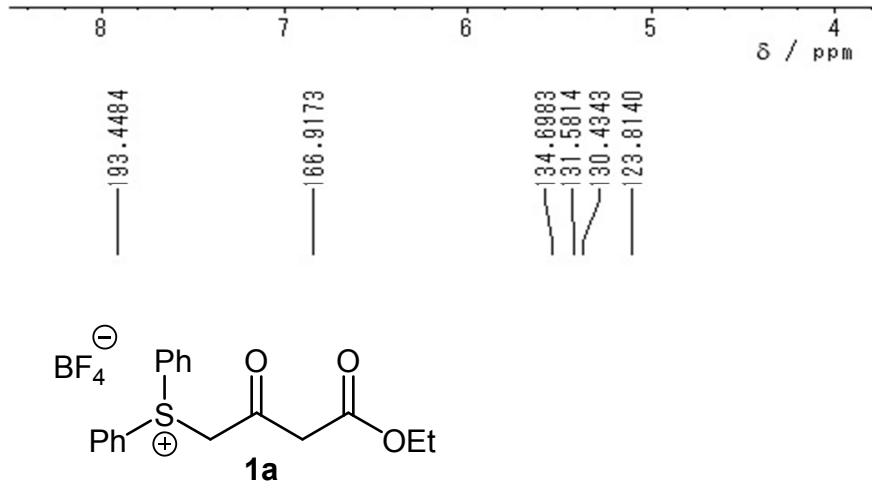

${ }^{13} \mathrm{C}$ NMR

(126 MHz, $\mathrm{CDCl}_{3}$ )

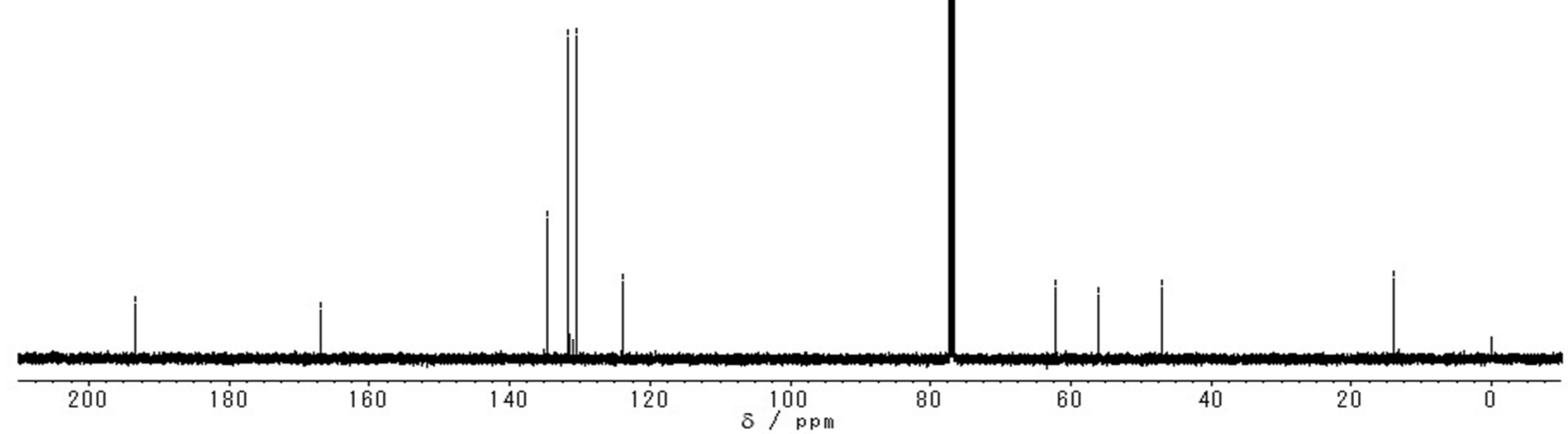



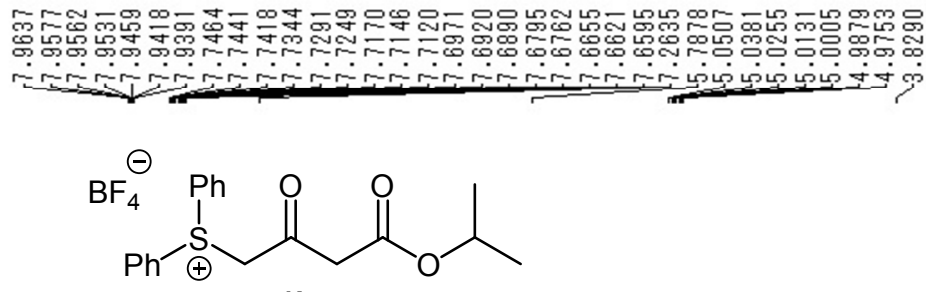

$1 b$

${ }^{1} \mathrm{H}$ NMR

(500 MHz, $\mathrm{CDCl}_{3}$ )
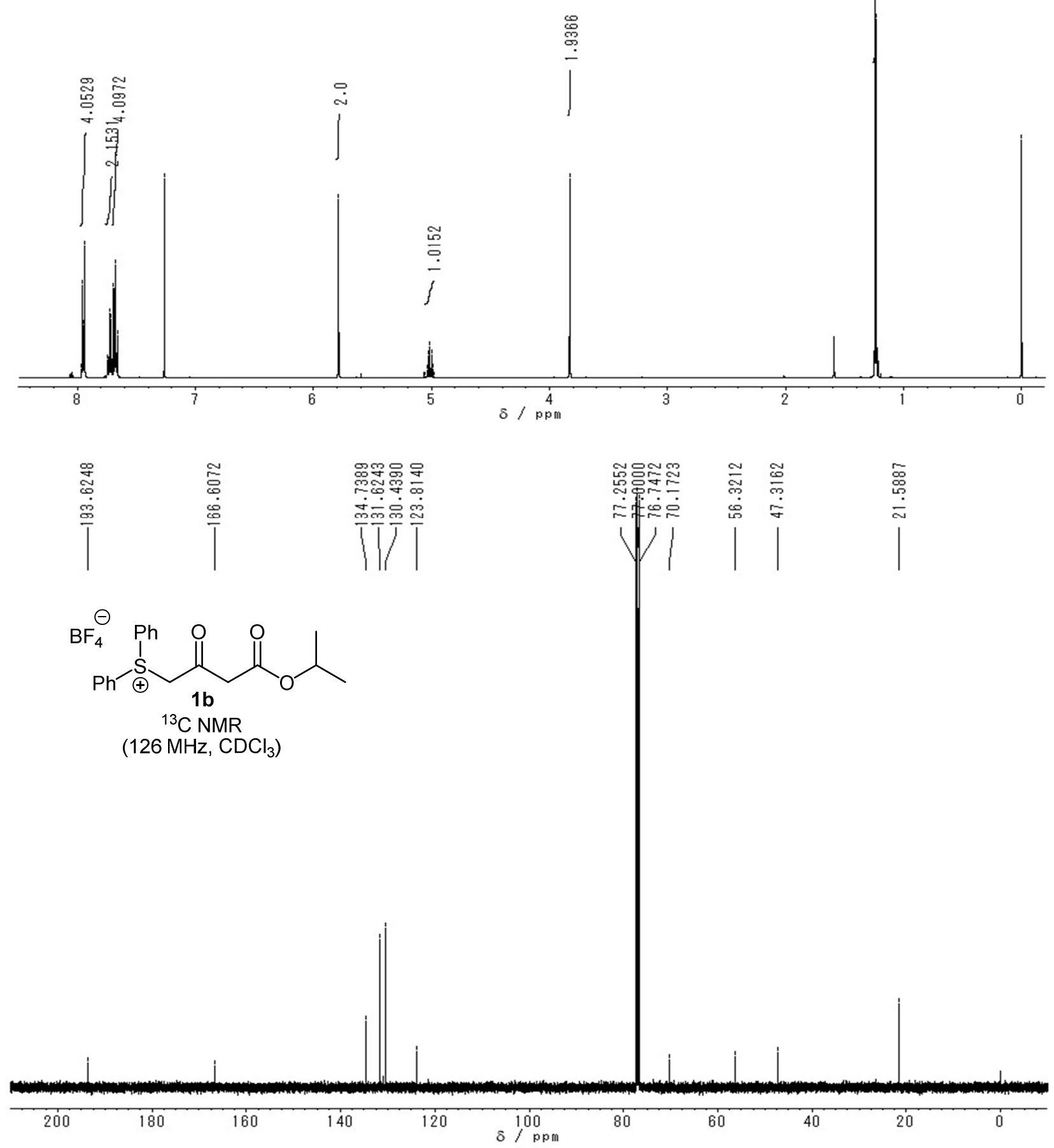

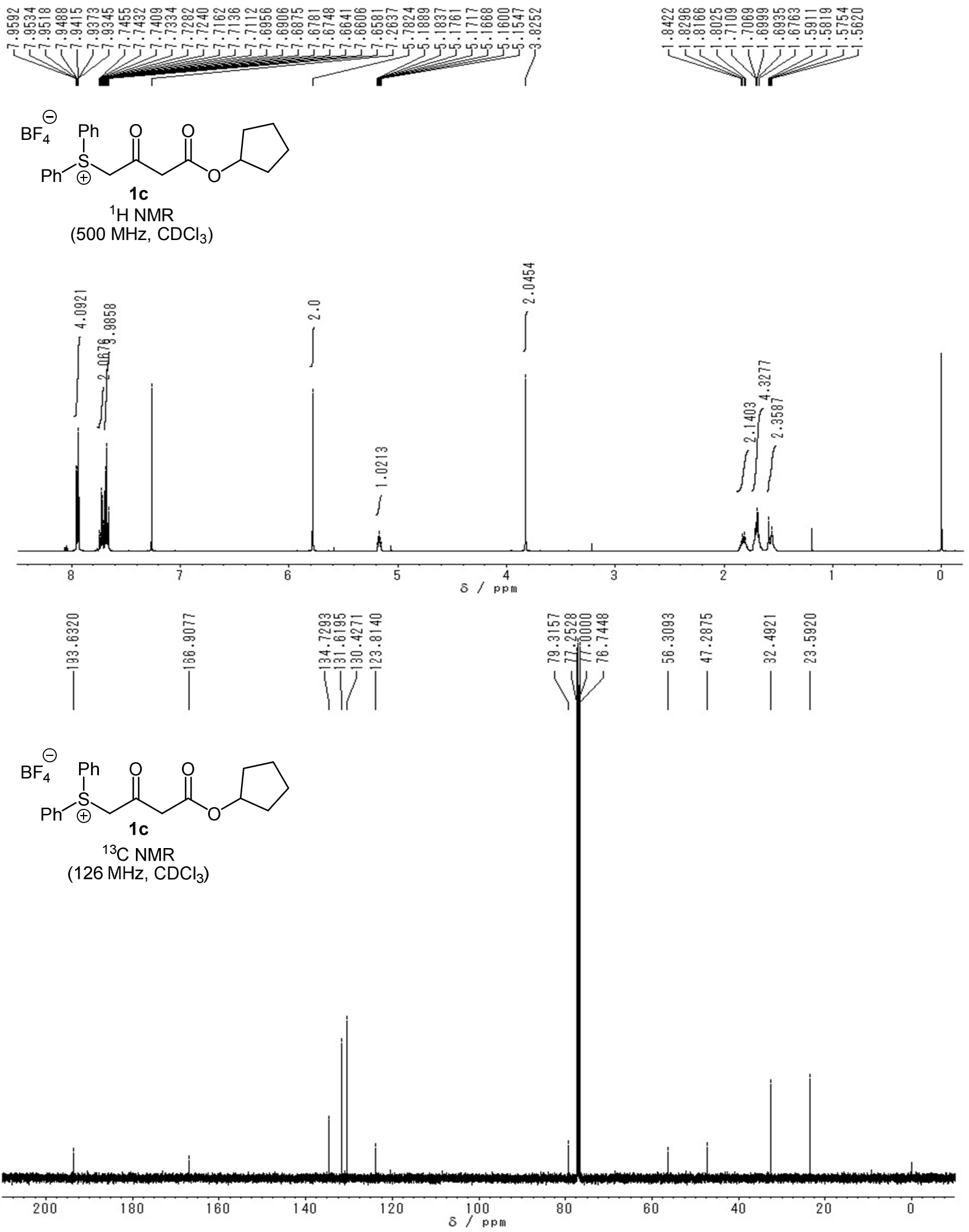

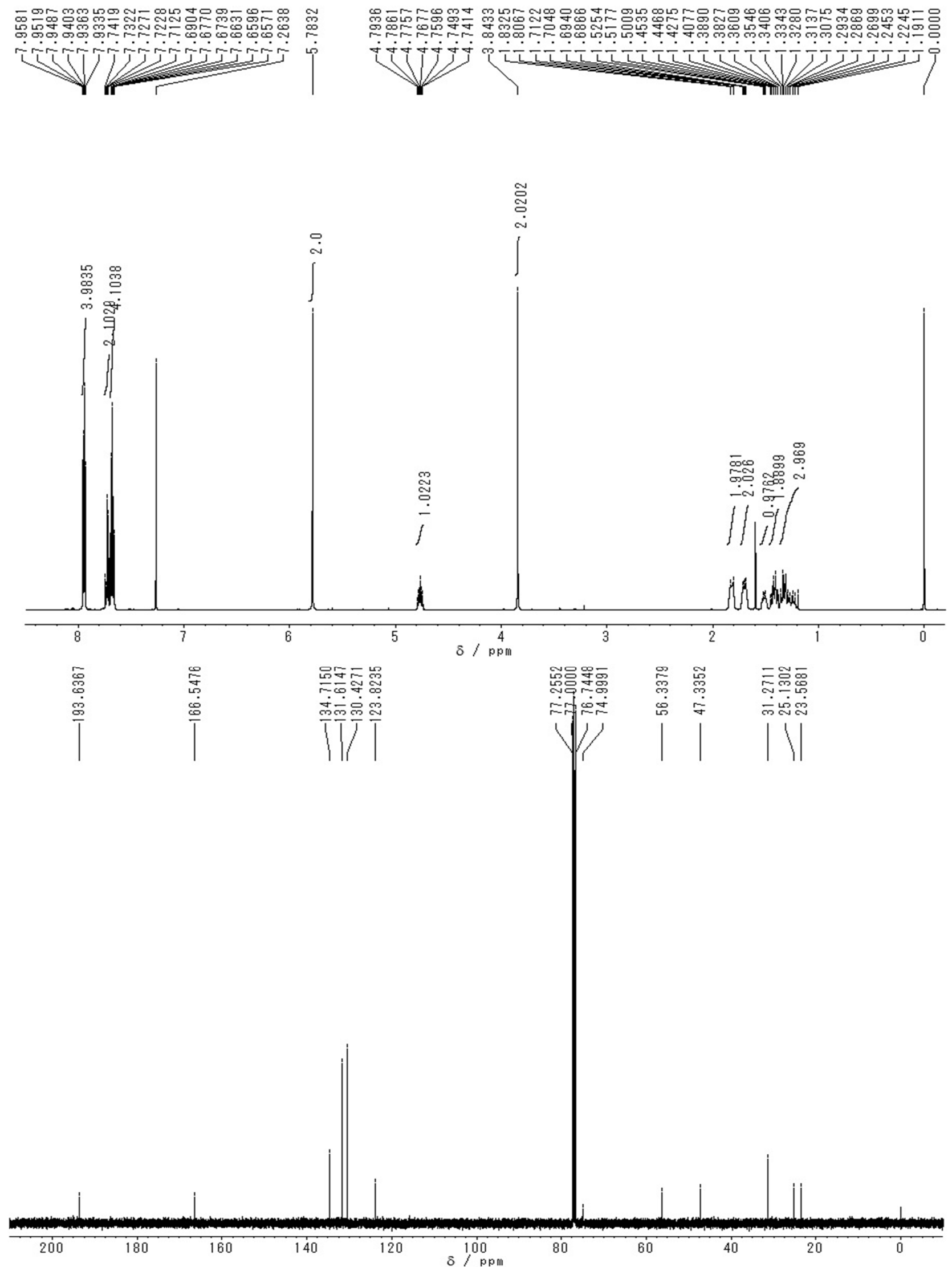

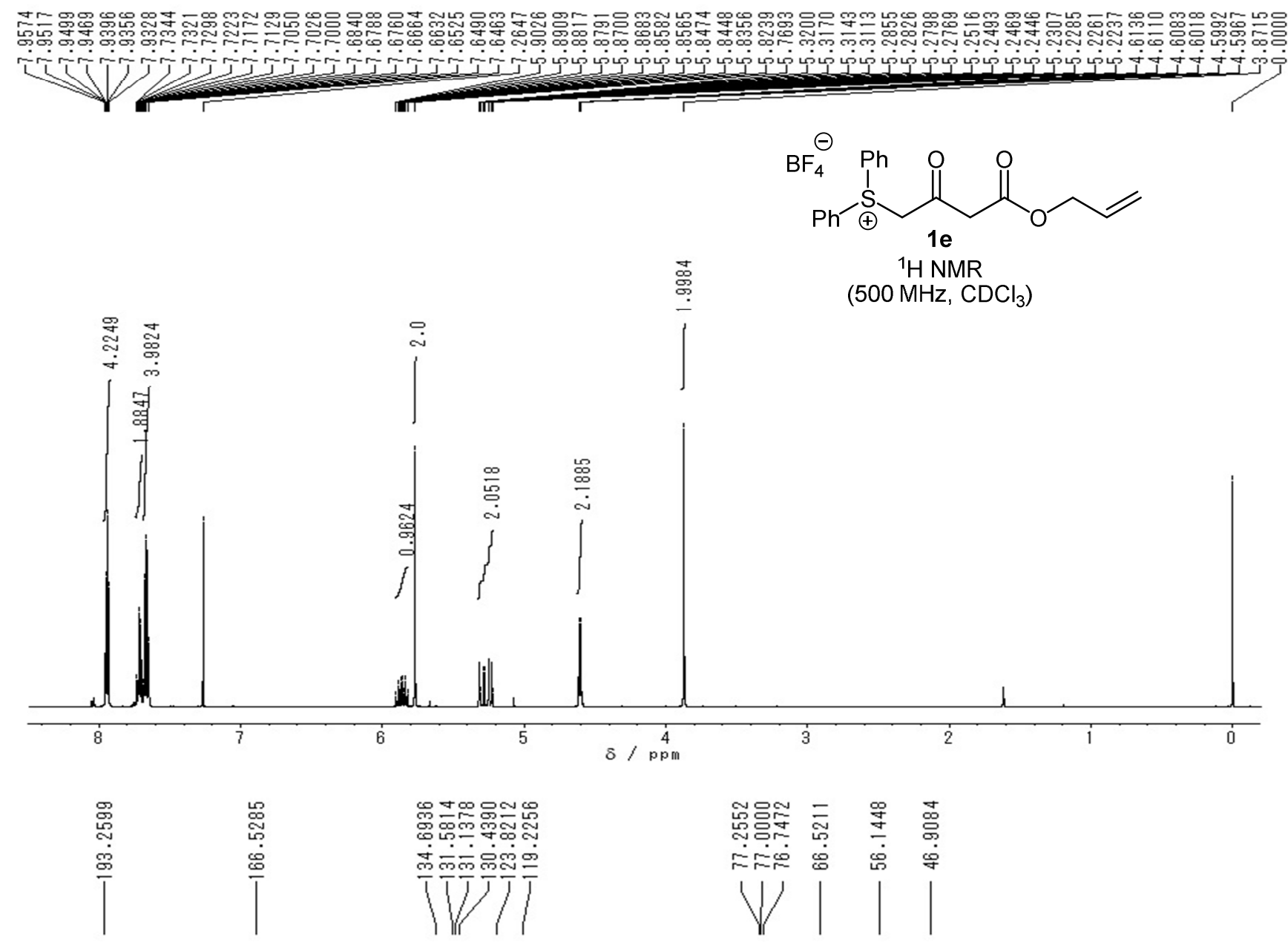

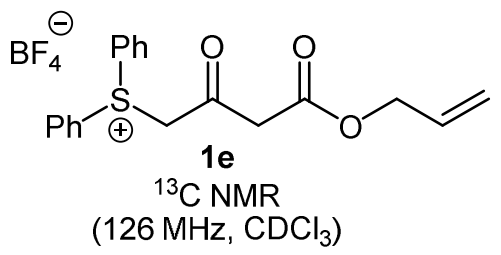

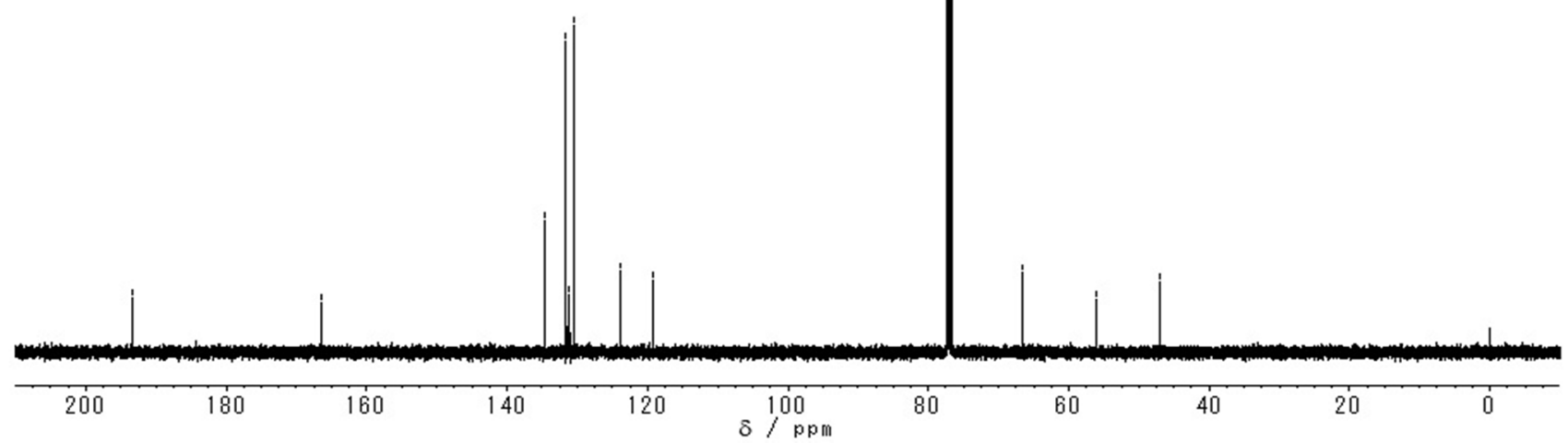

S15 

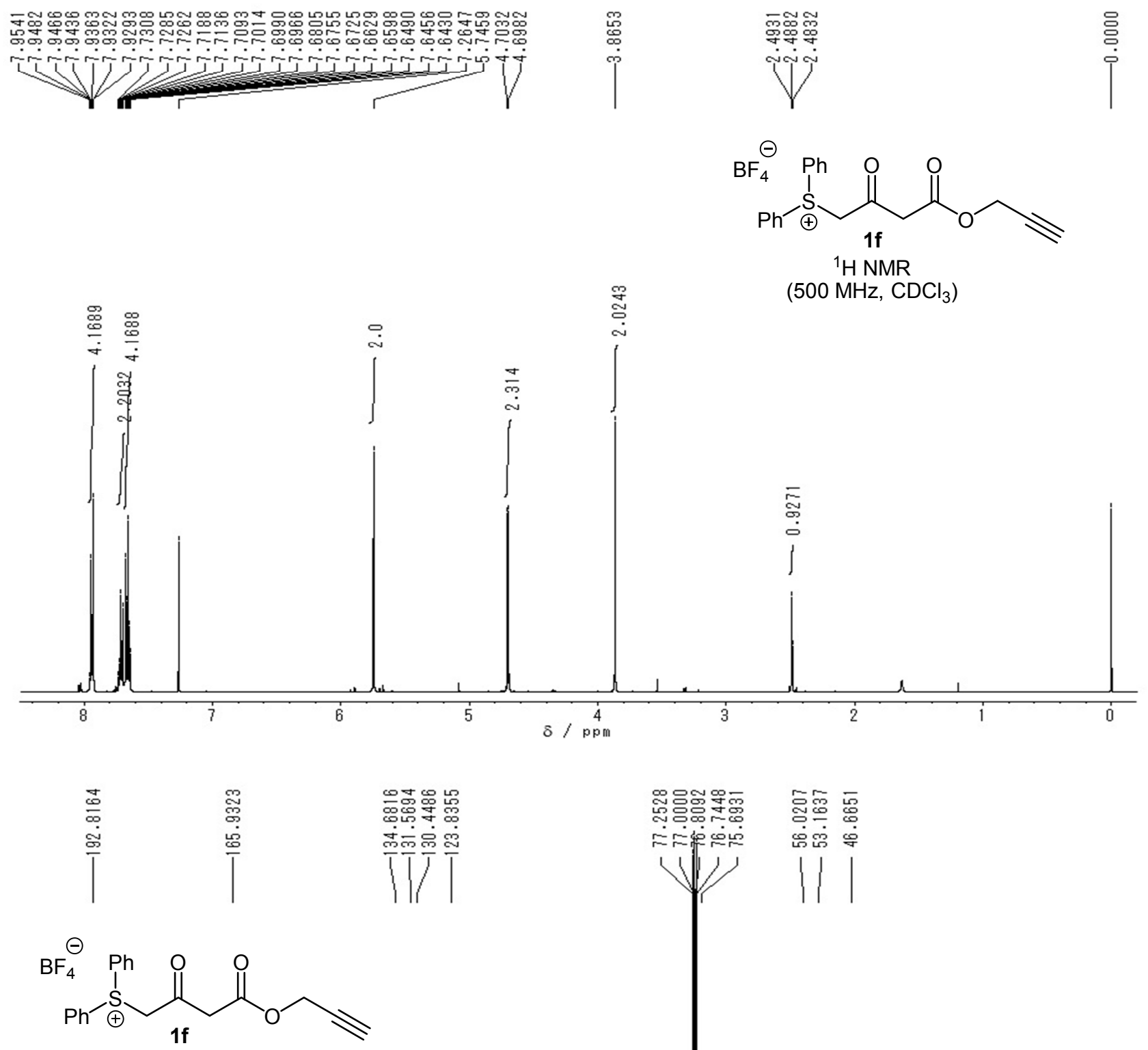

${ }^{13} \mathrm{C}$ NMR (126 MHz, $\mathrm{CDCl}_{3}$ )

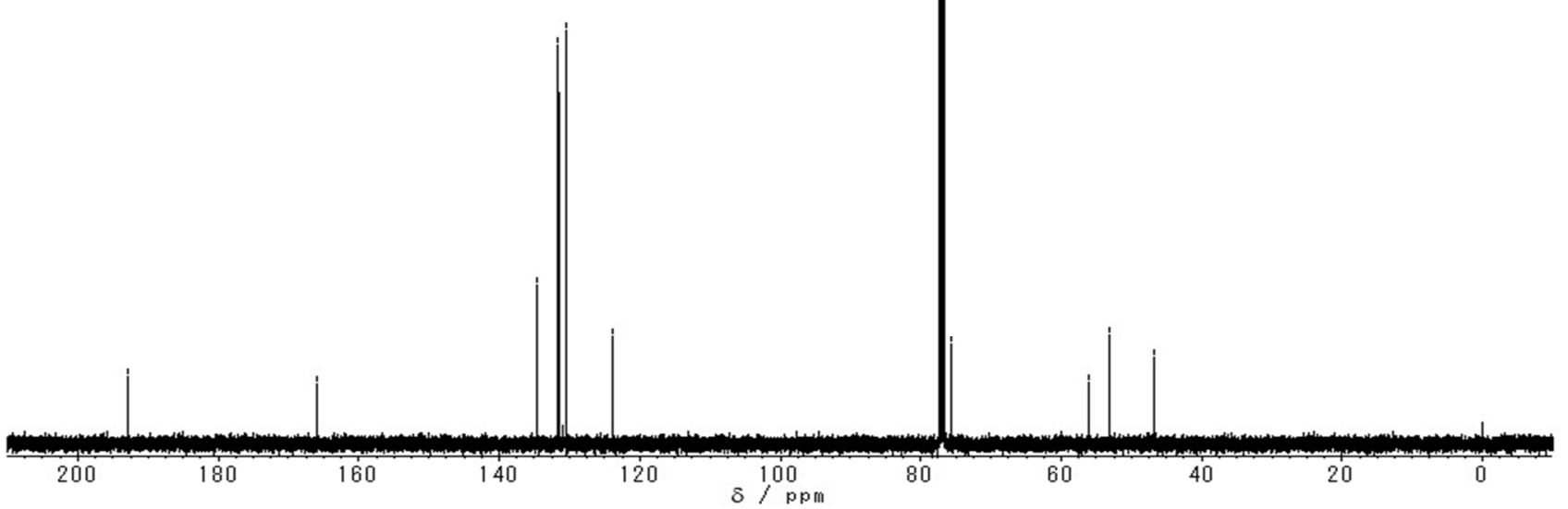



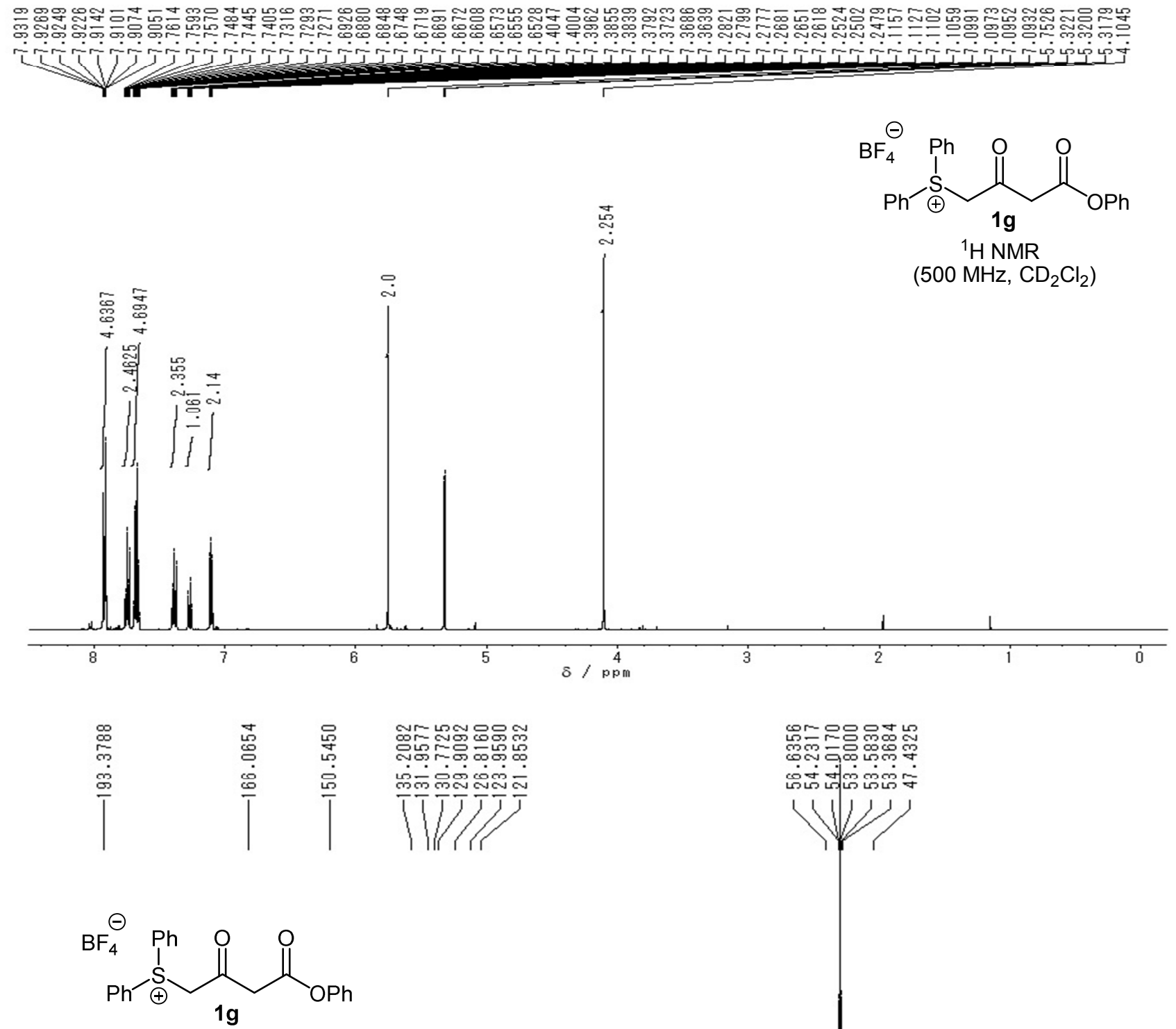

${ }^{13} \mathrm{C}$ NMR

(126 MHz, $\mathrm{CD}_{2} \mathrm{Cl}_{2}$ )

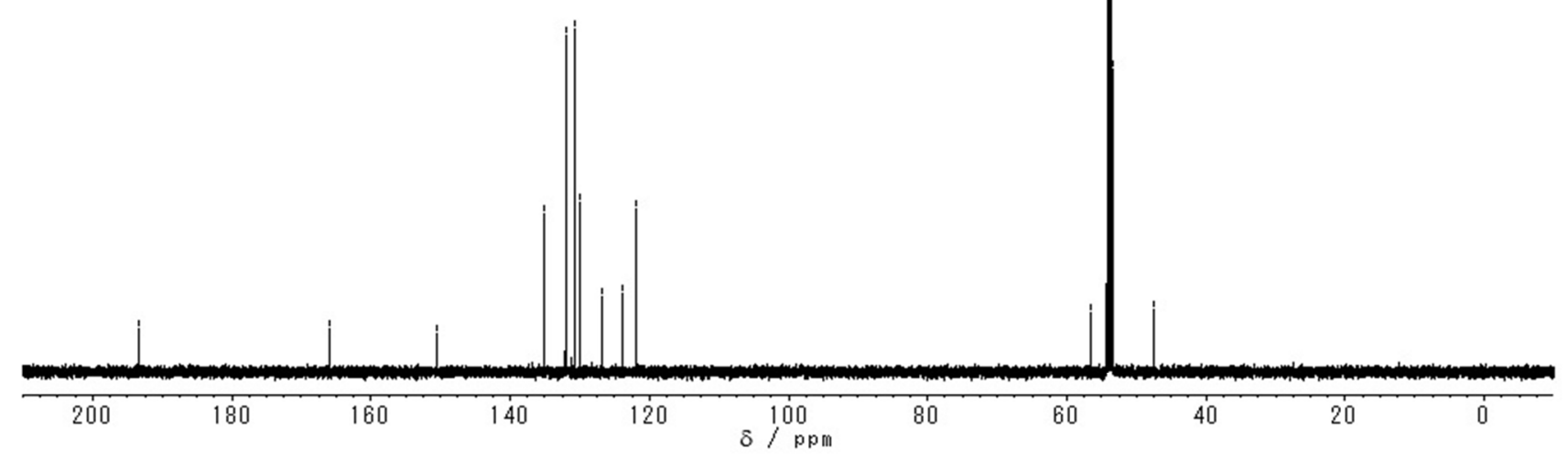




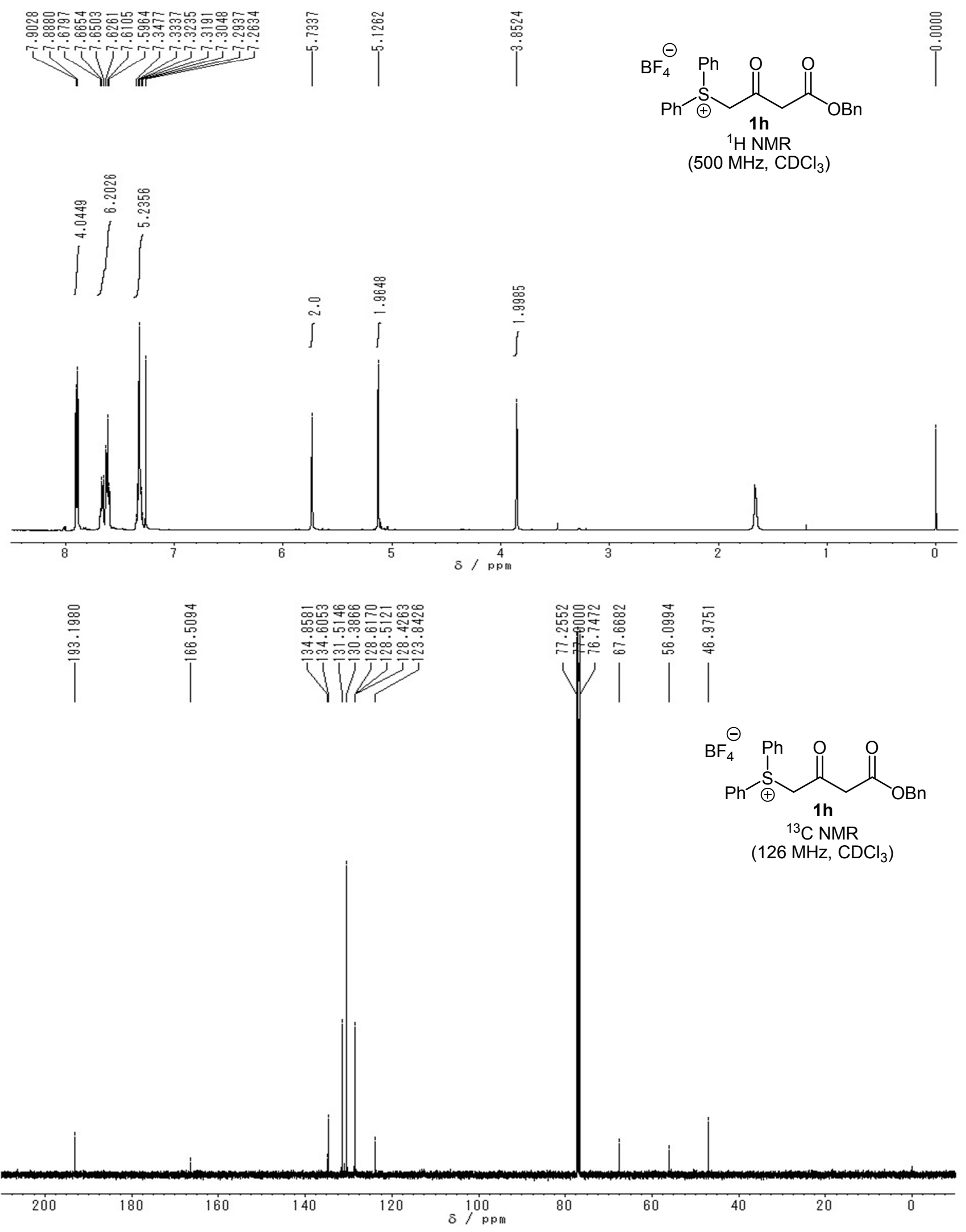



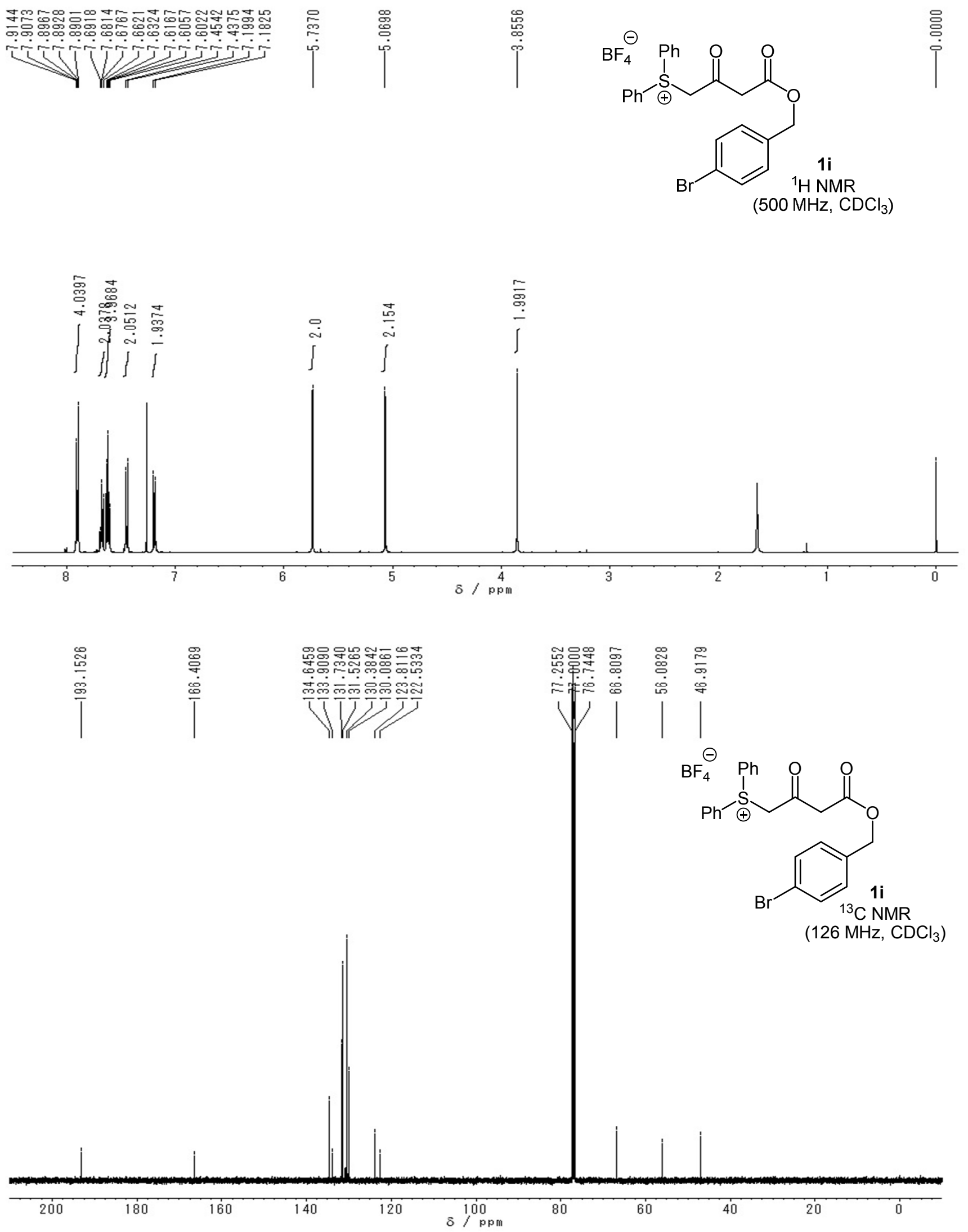


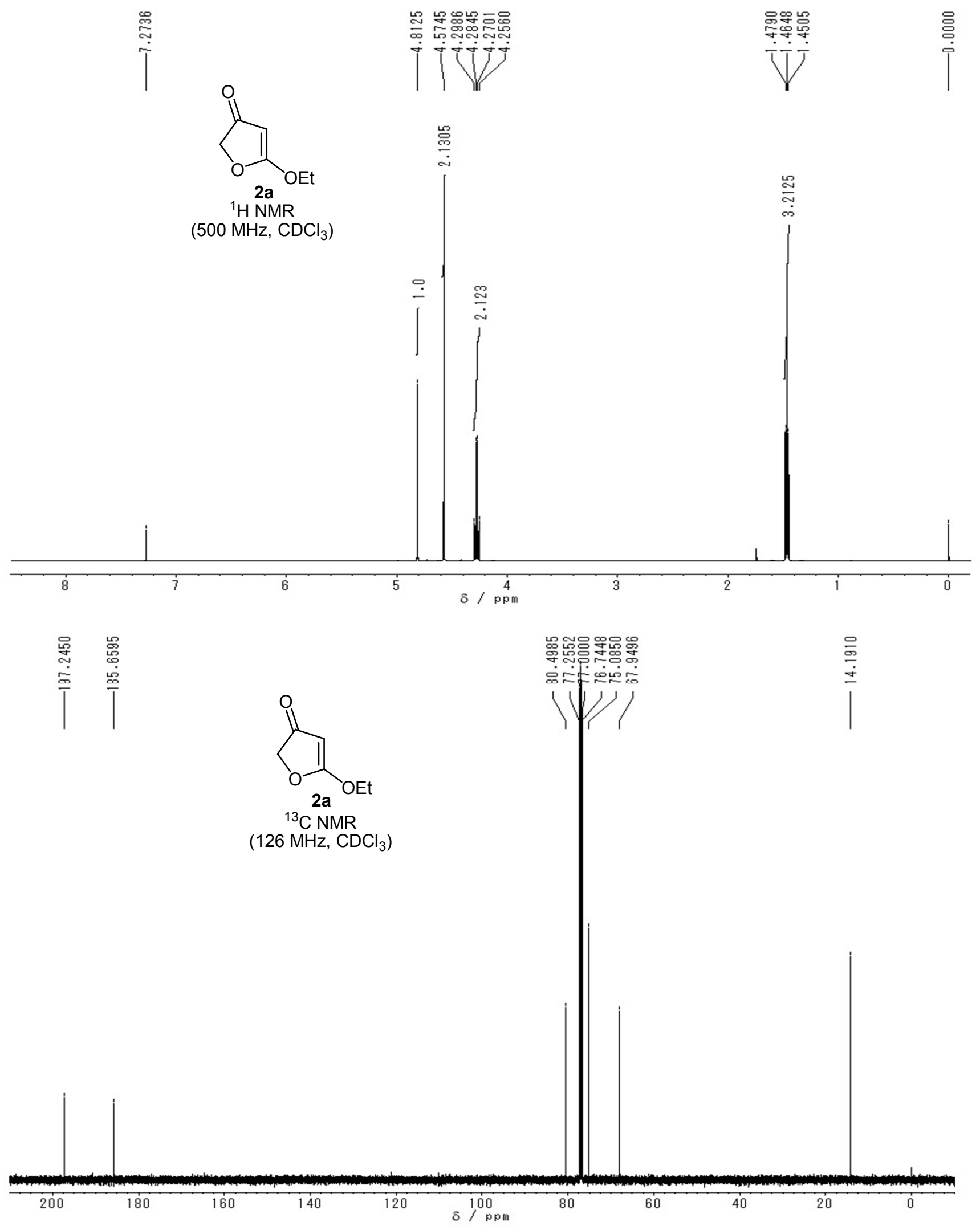




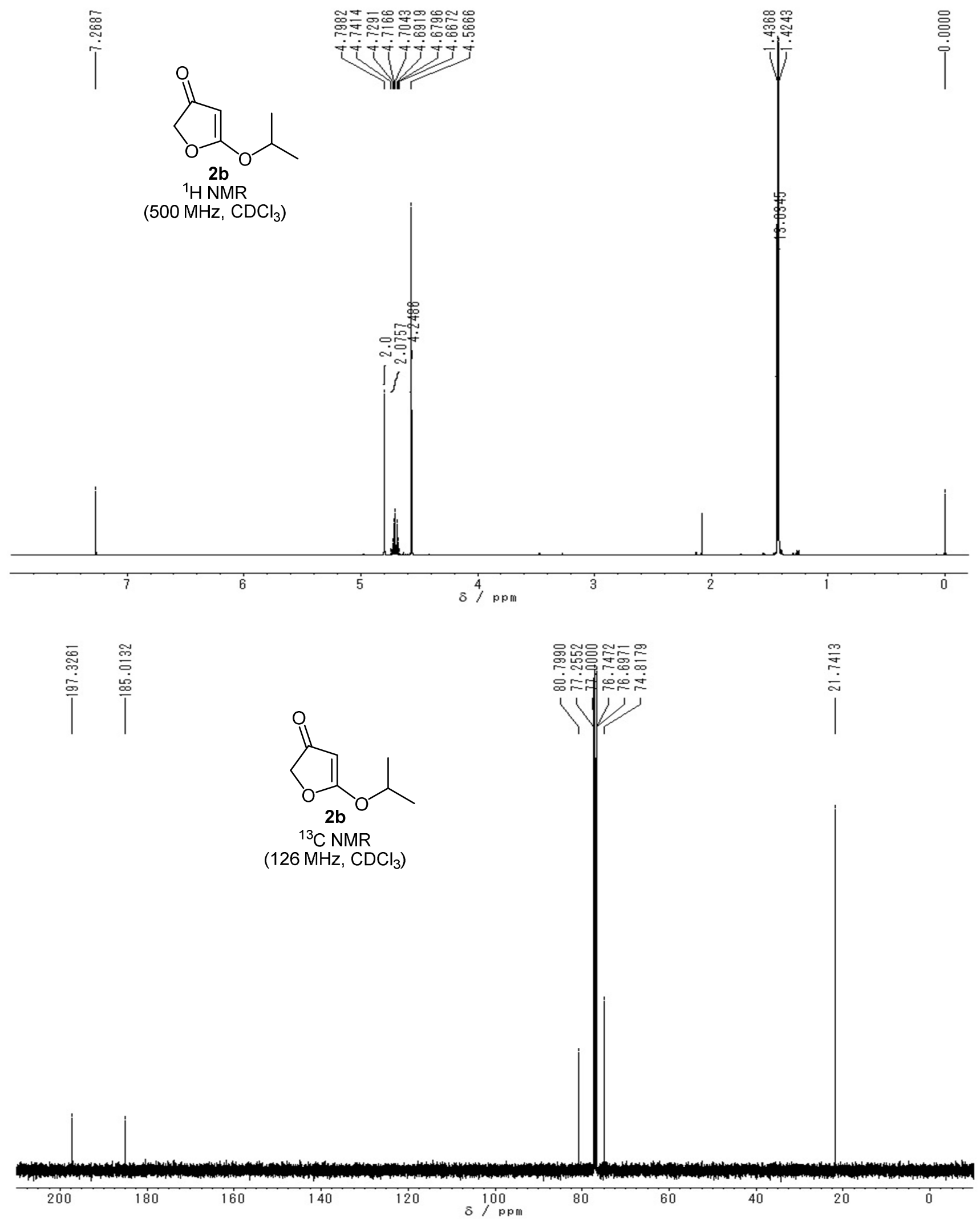




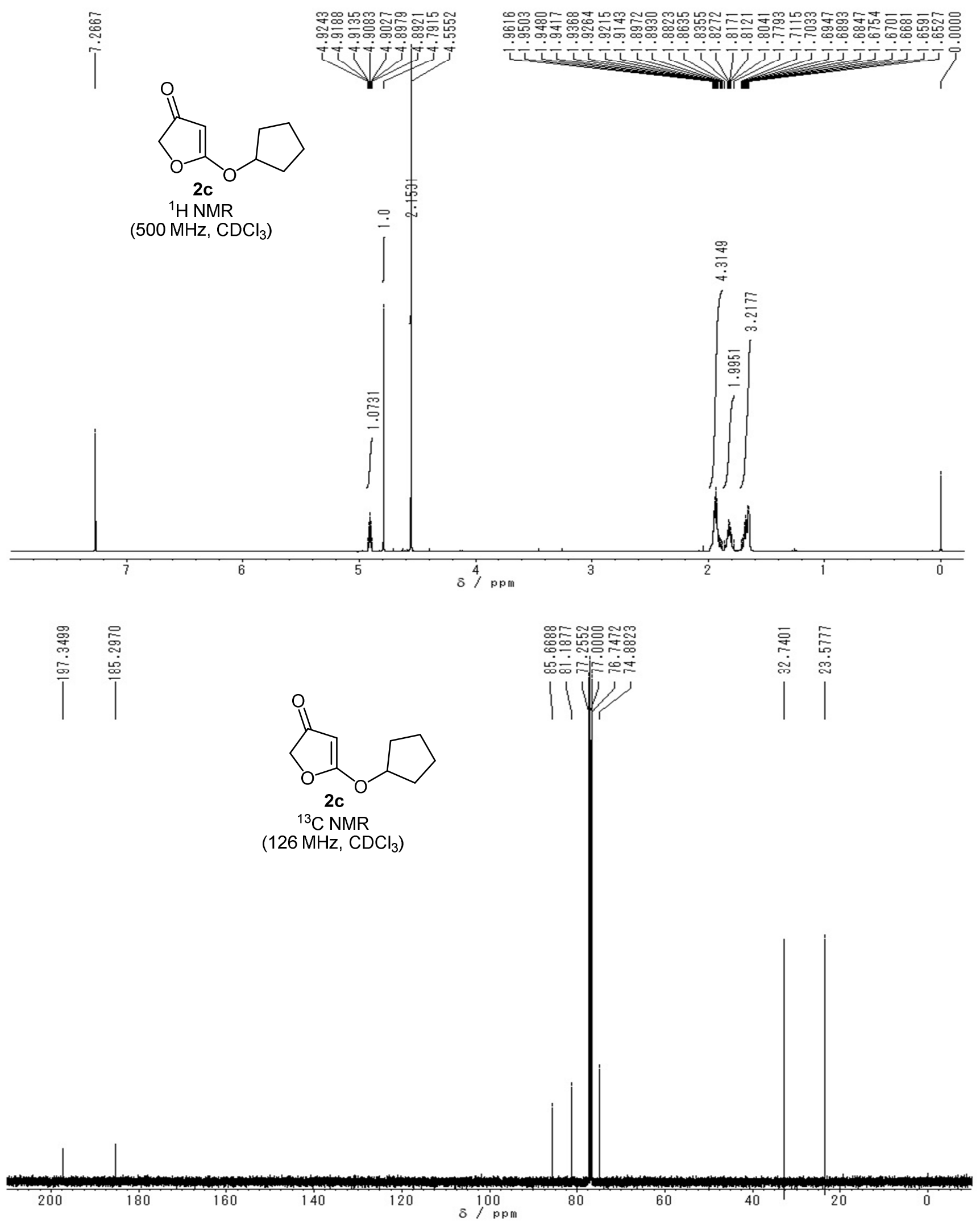



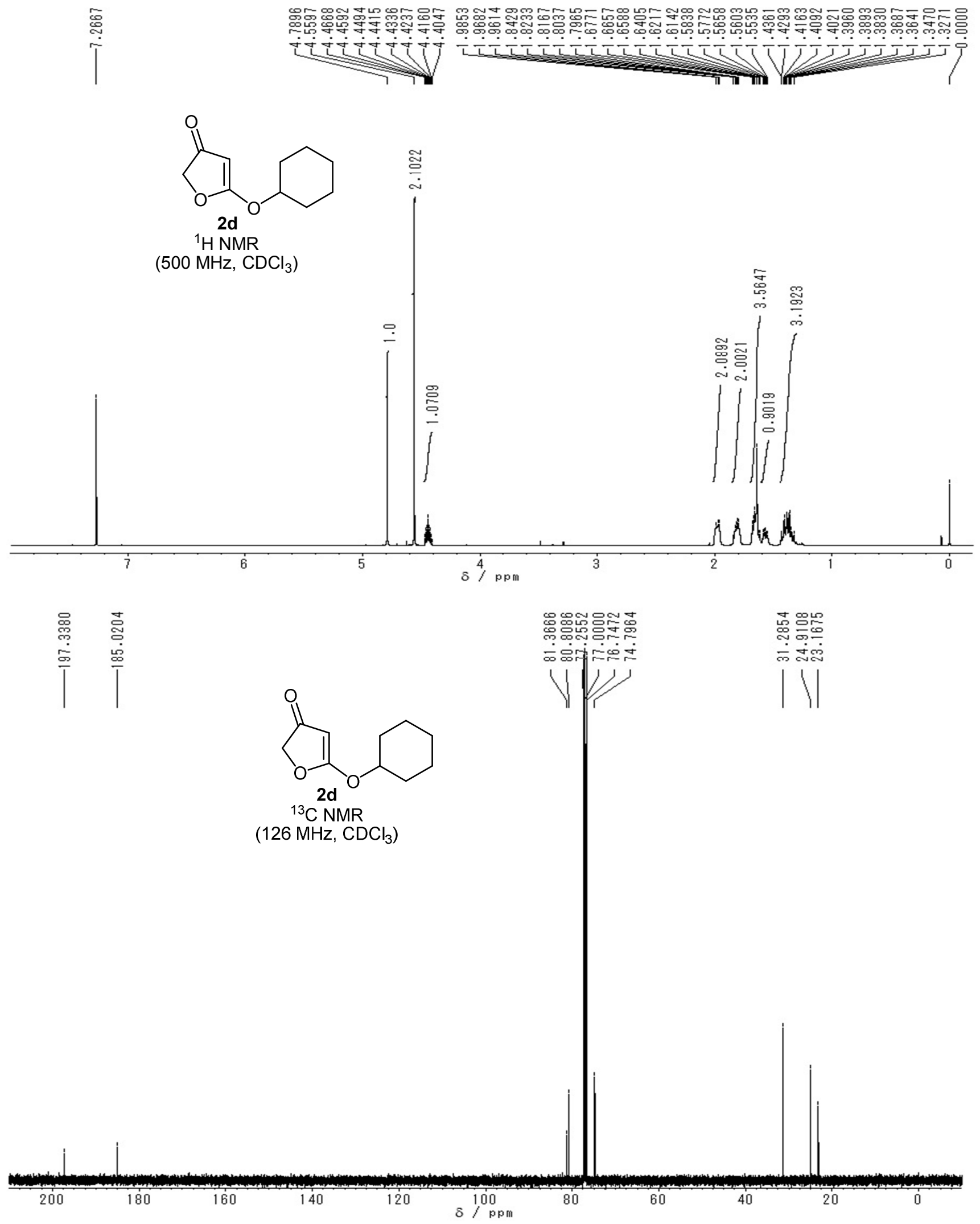

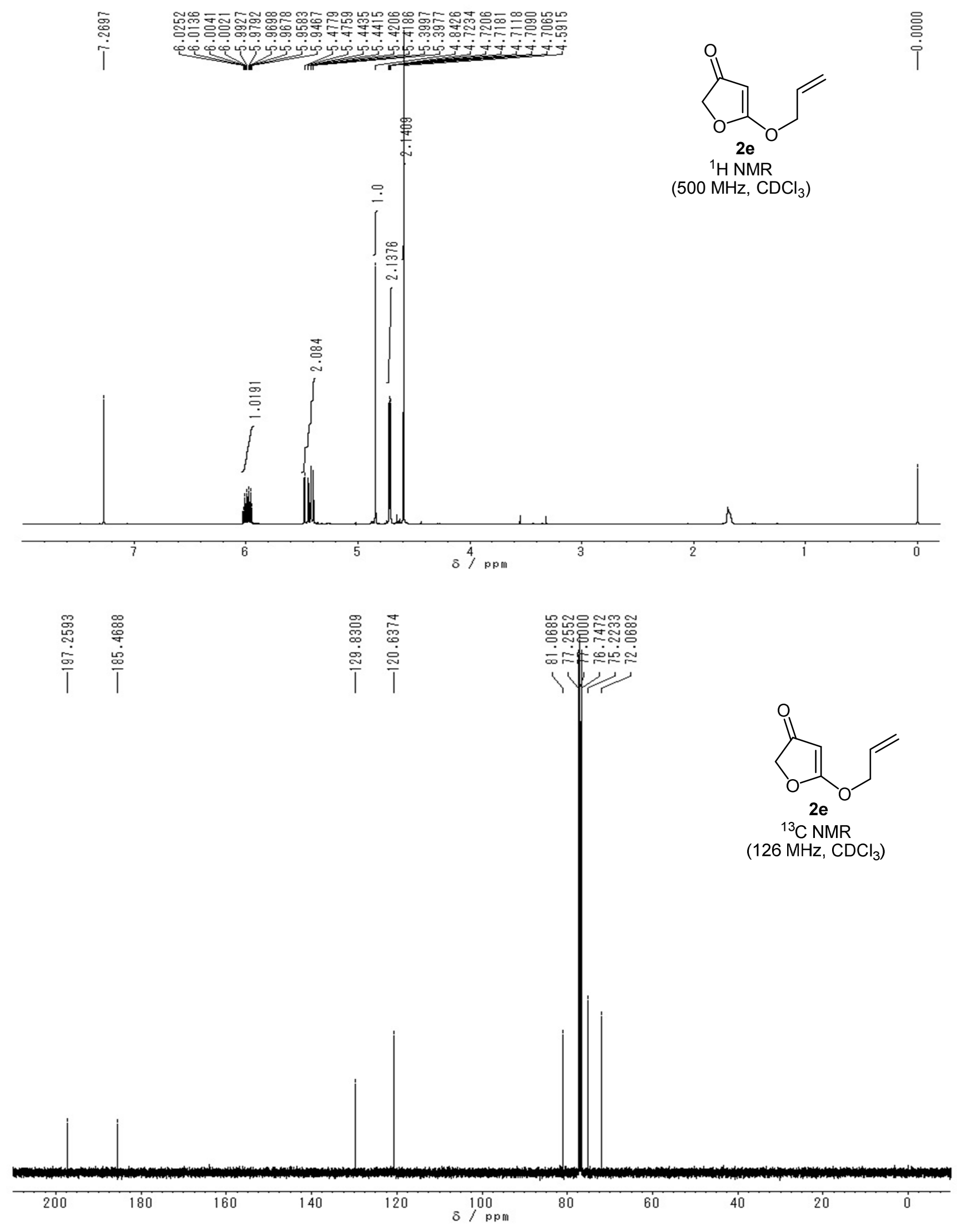


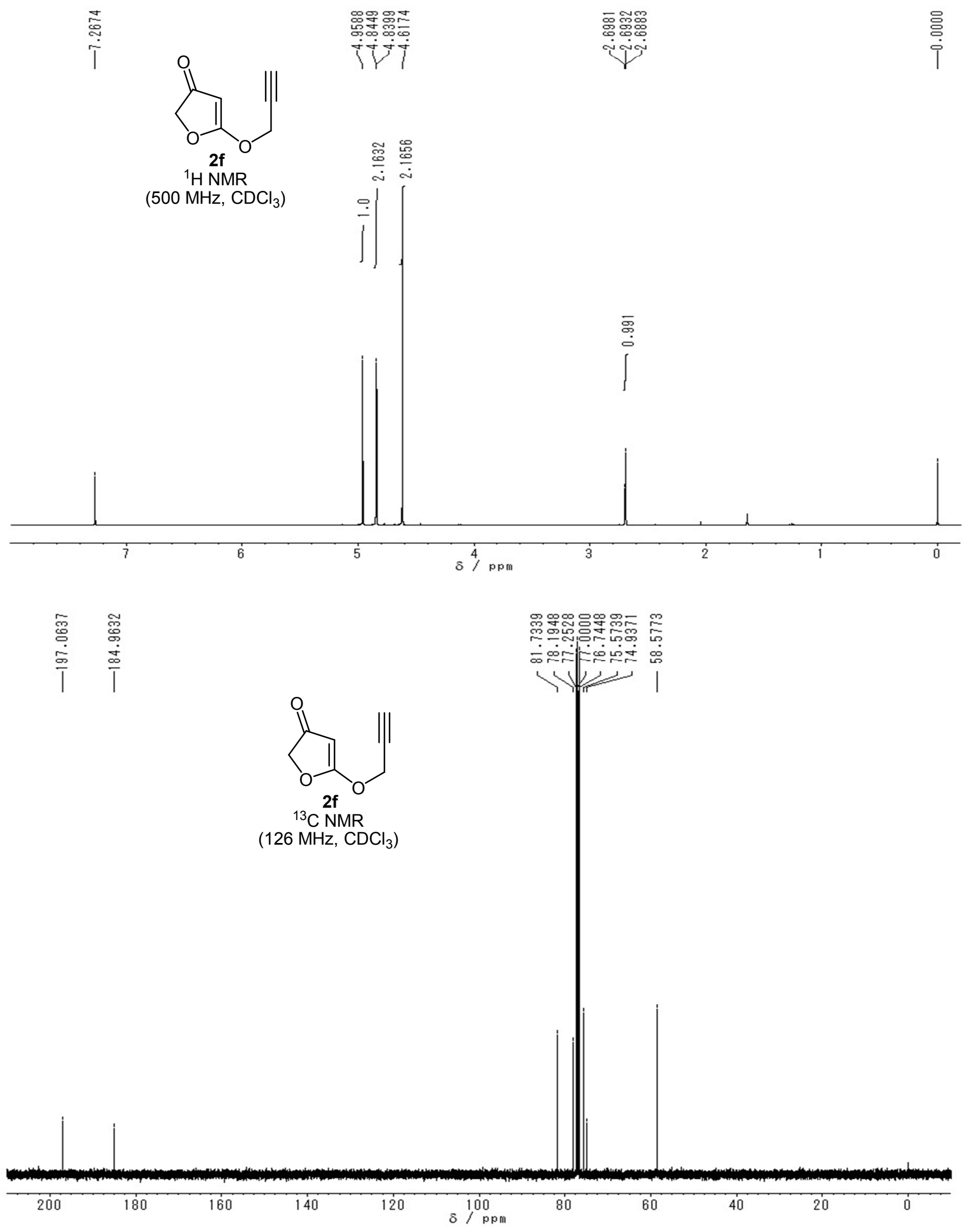




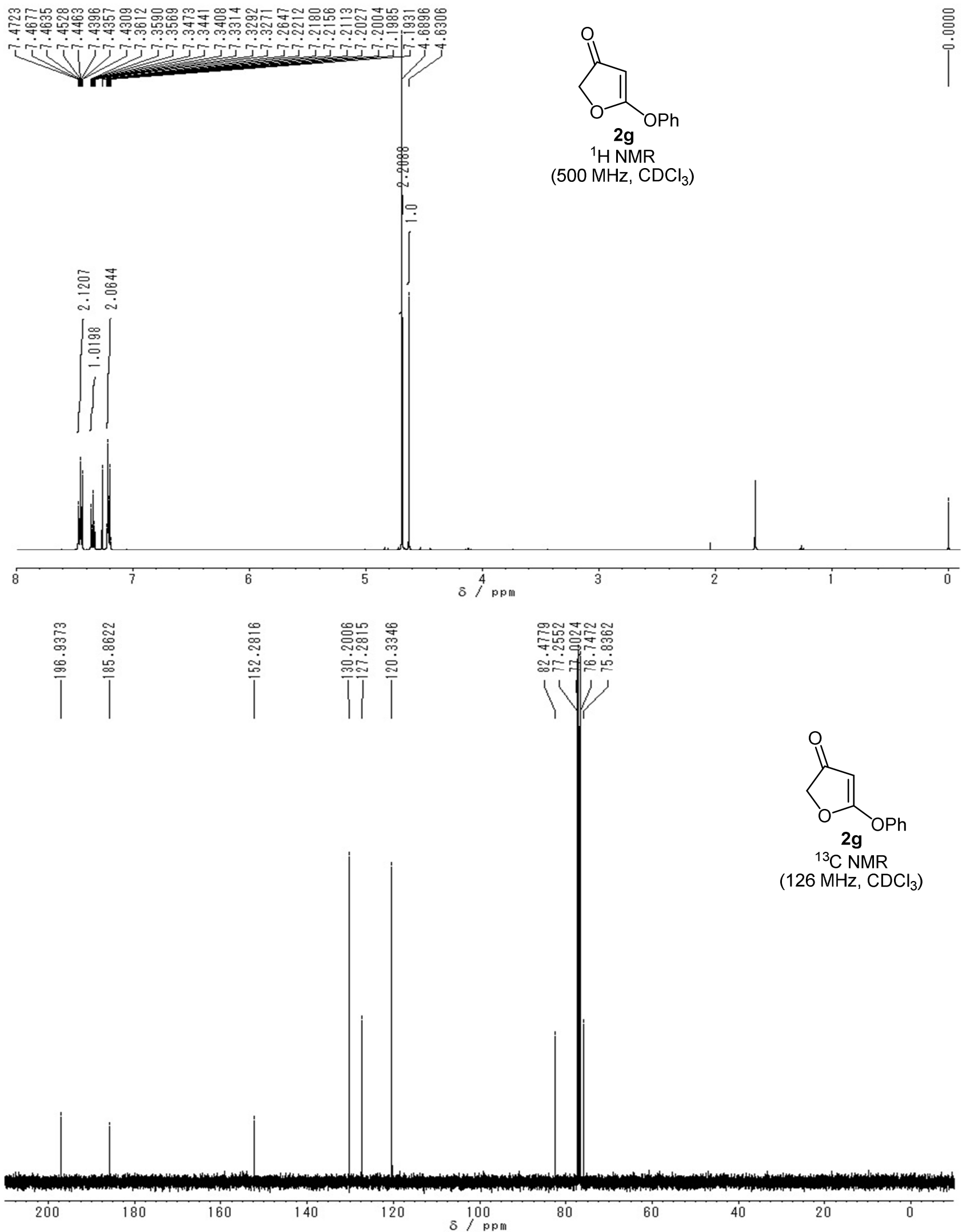




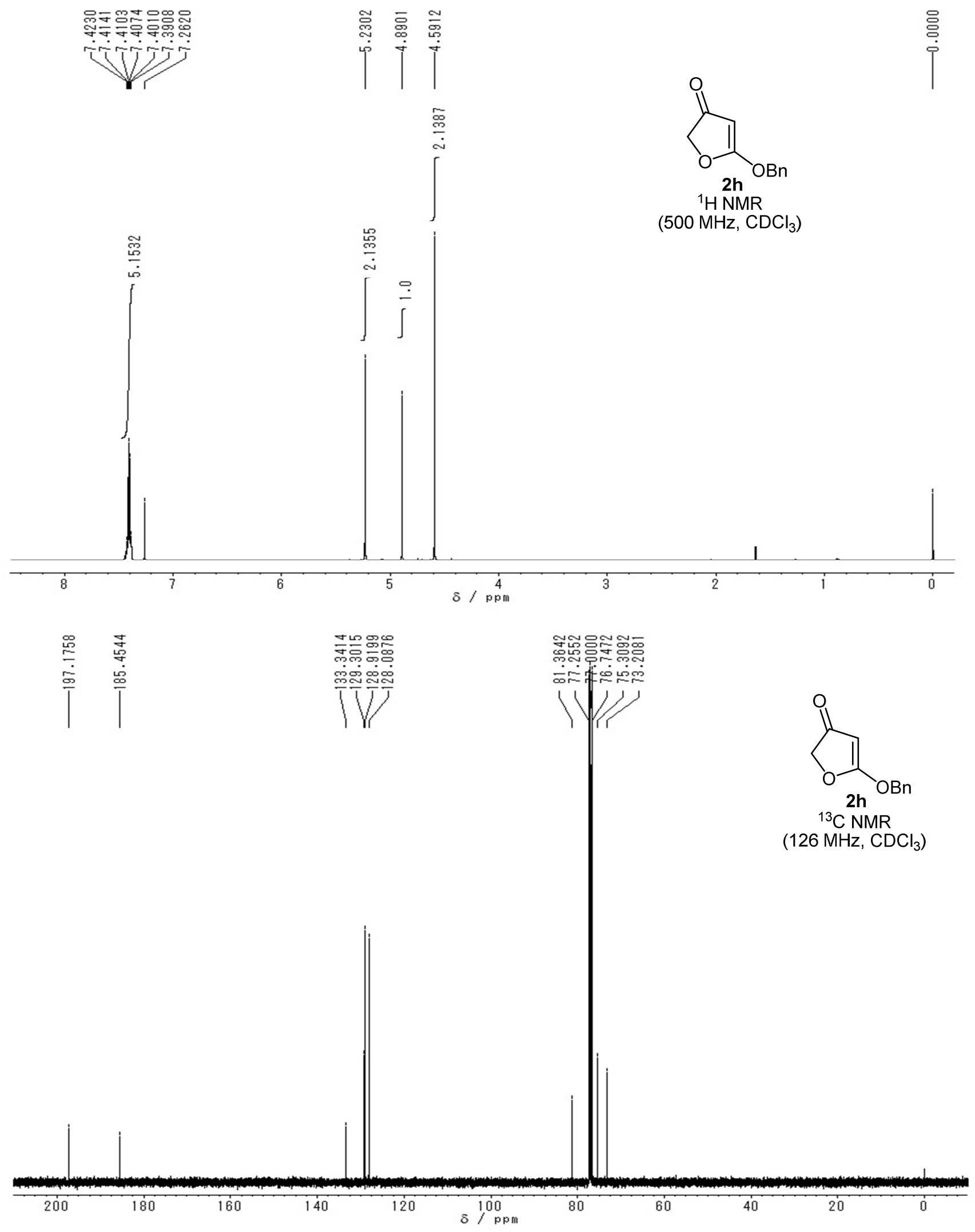




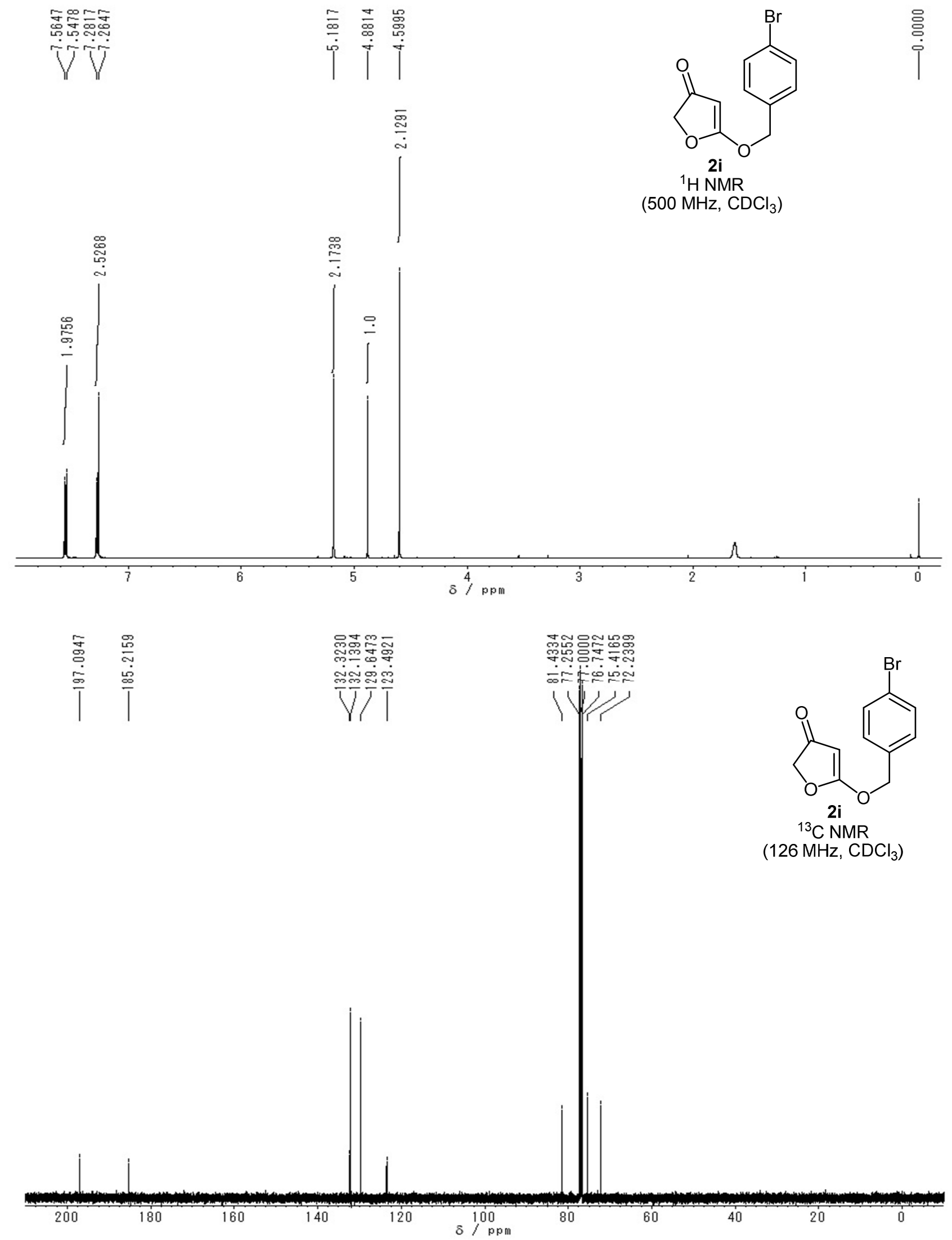



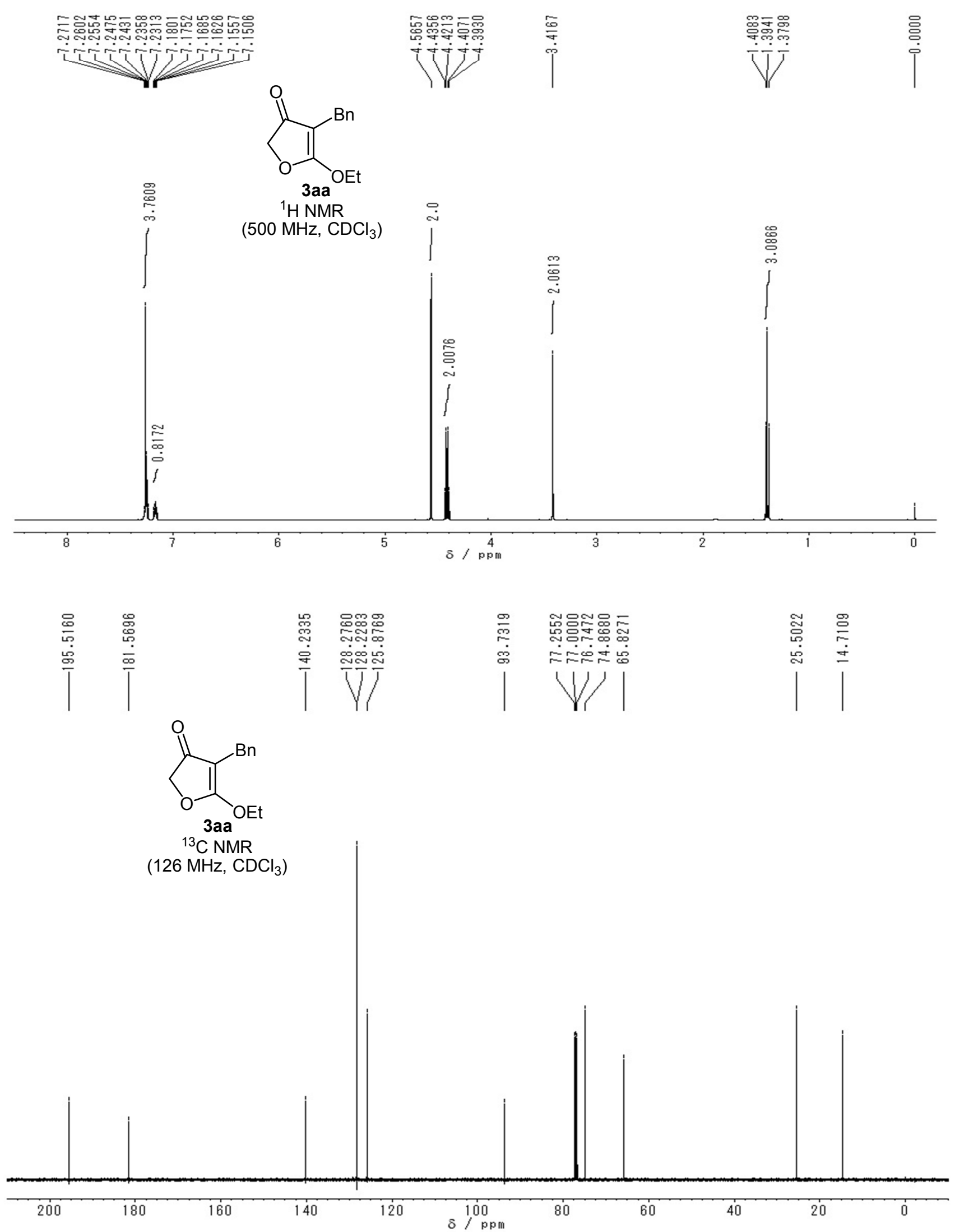

S29 


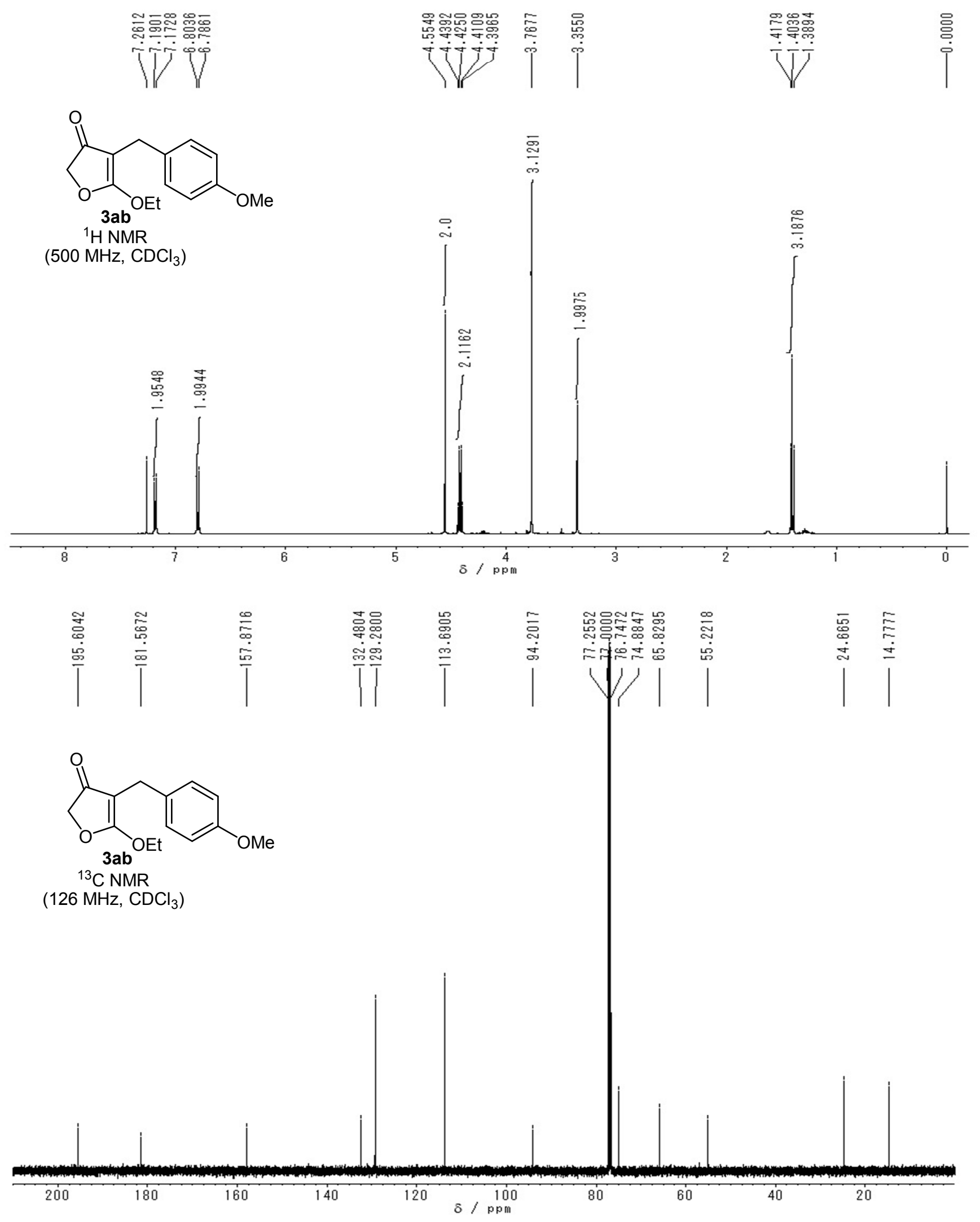




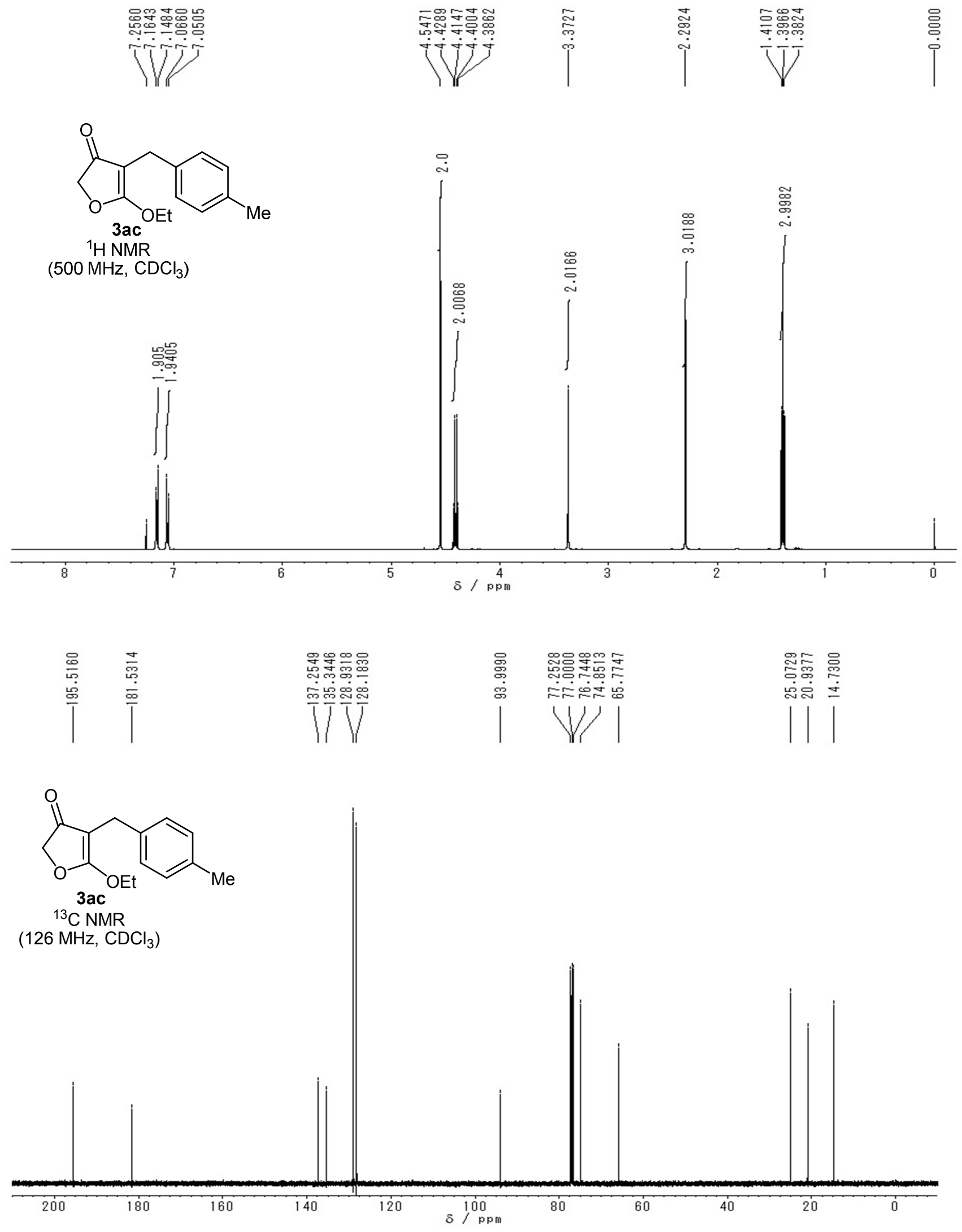




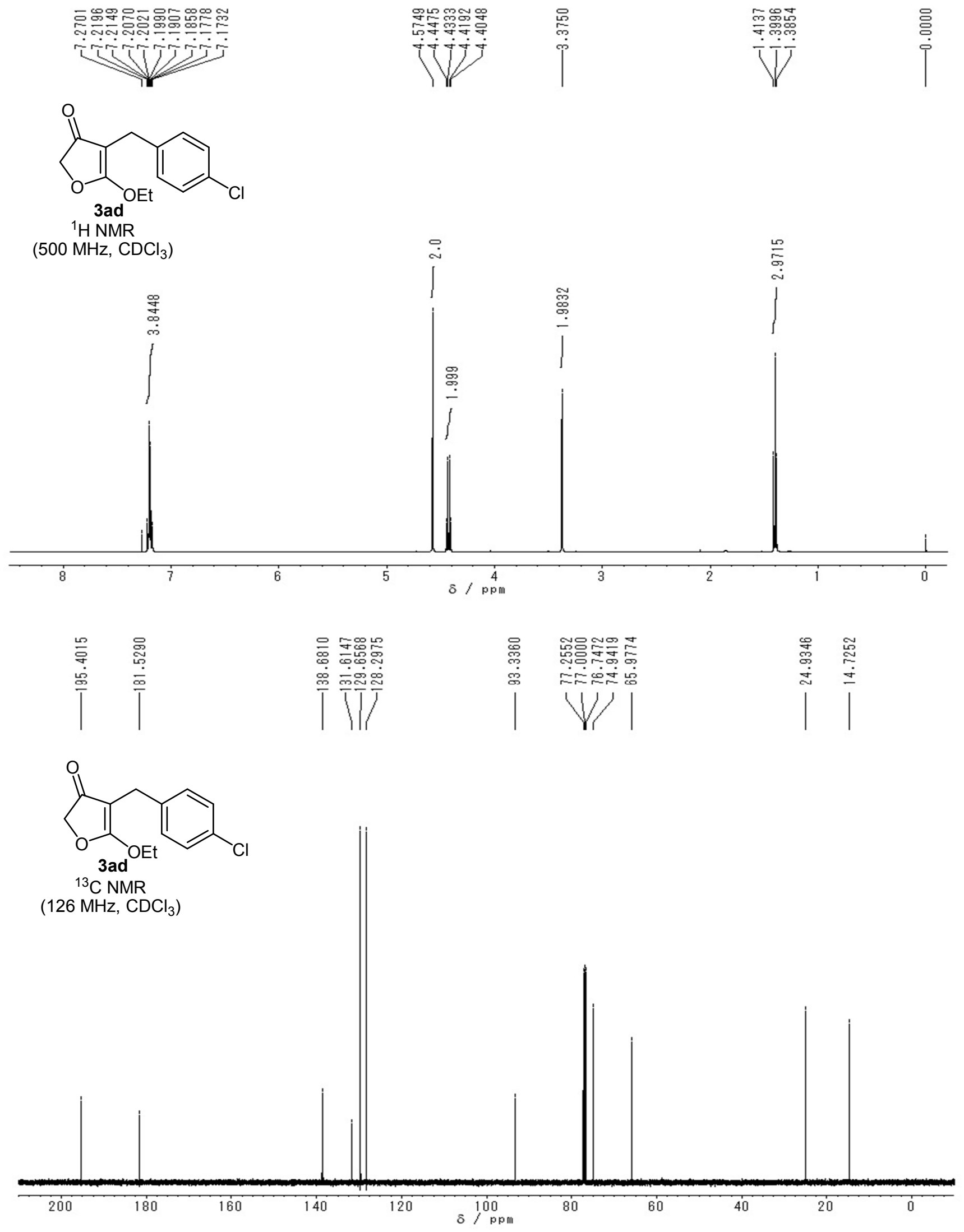

S32 


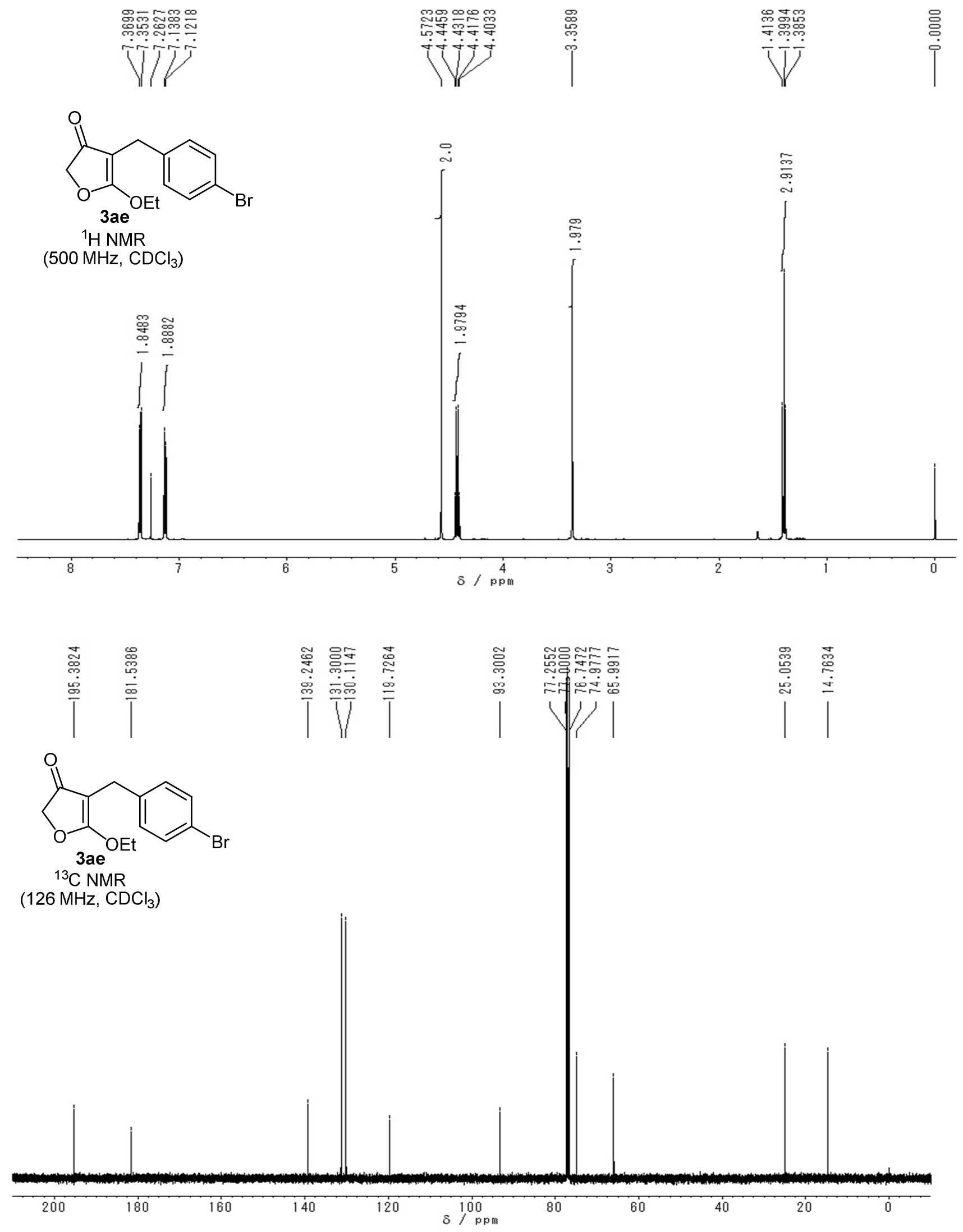

S33 

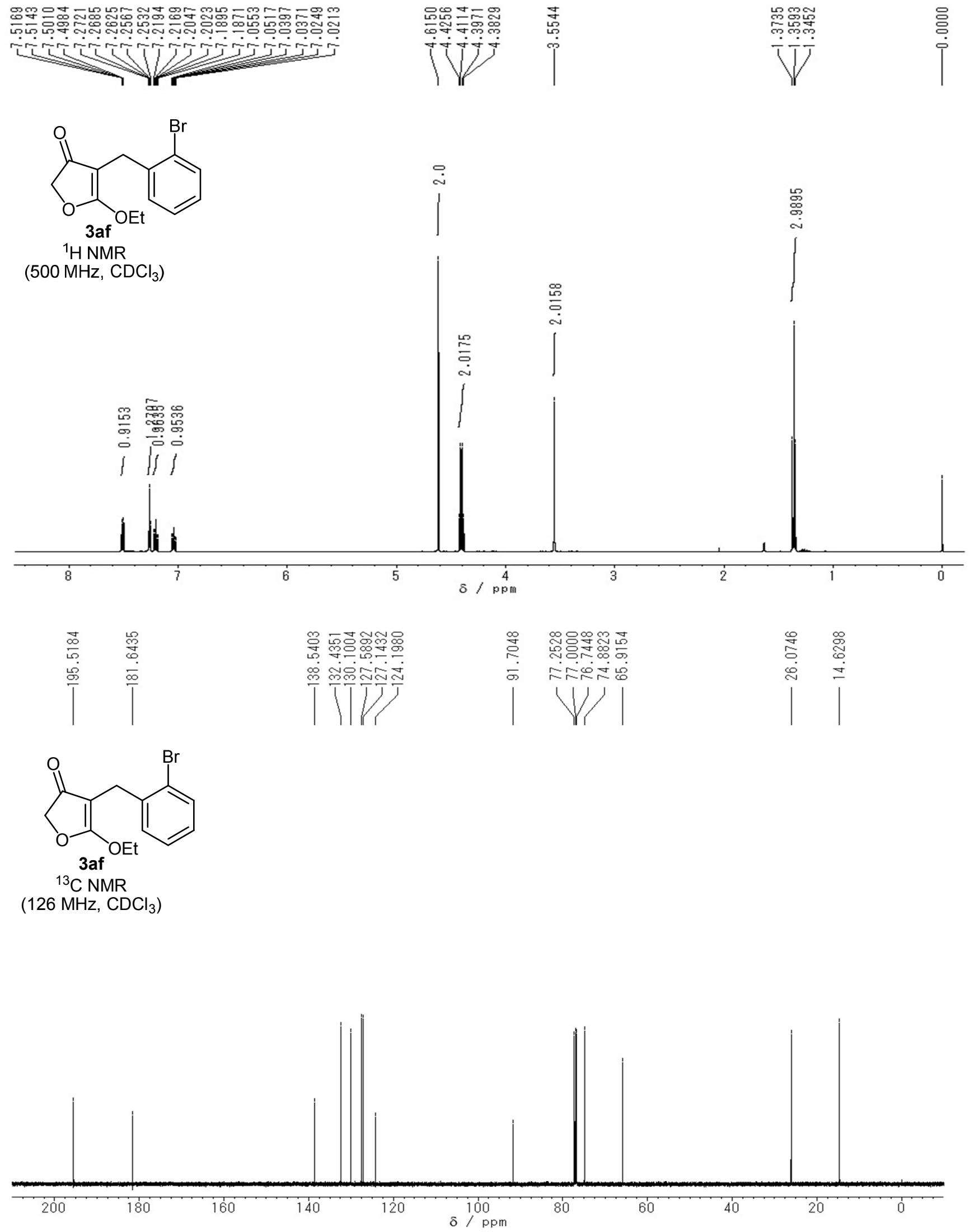

S34 

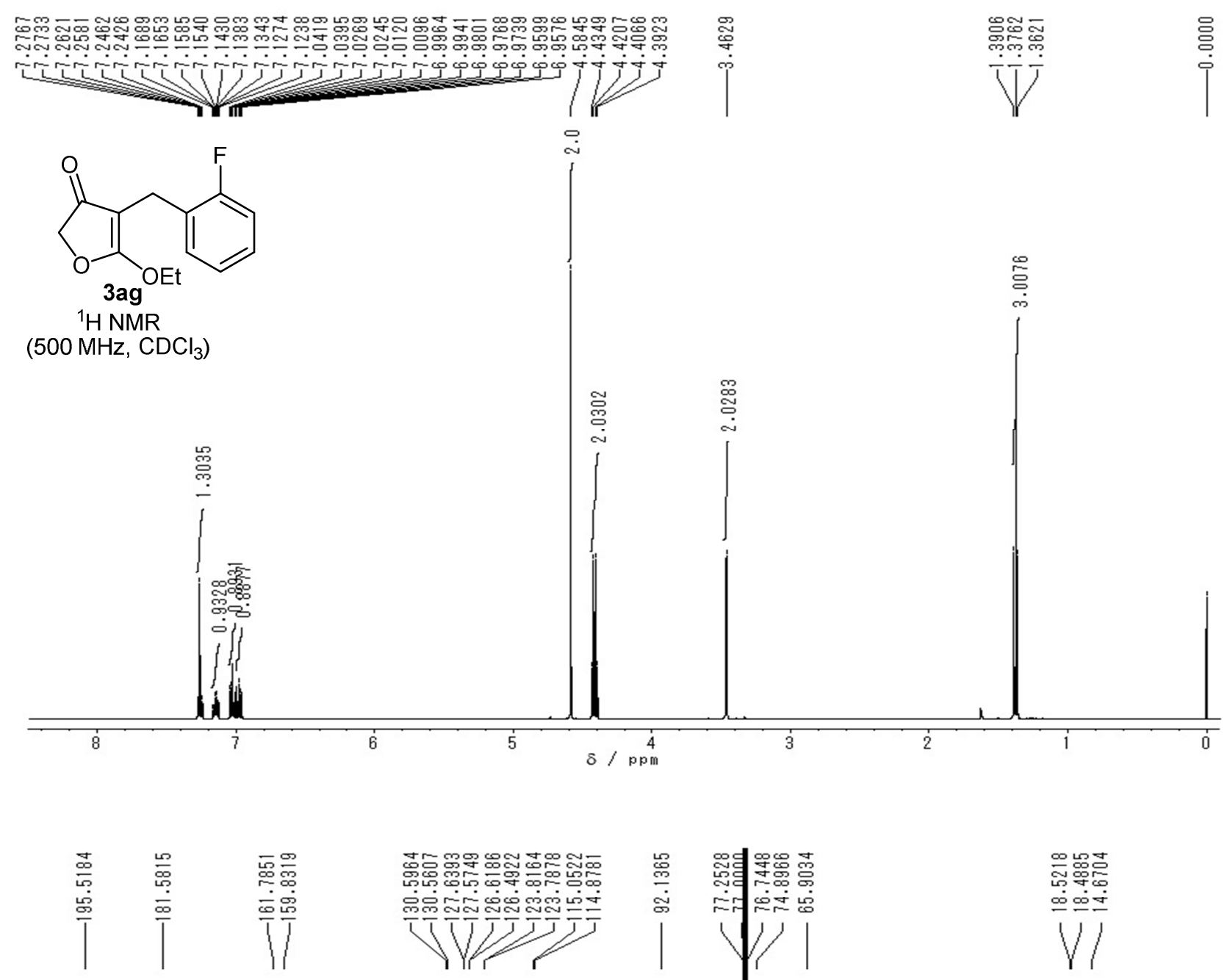<smiles>CCOC1=C(Cc2ccccc2F)C(=O)CO1</smiles>

${ }^{13} \mathrm{C}$ NMR

(126 MHz, $\mathrm{CDCl}_{3}$ )

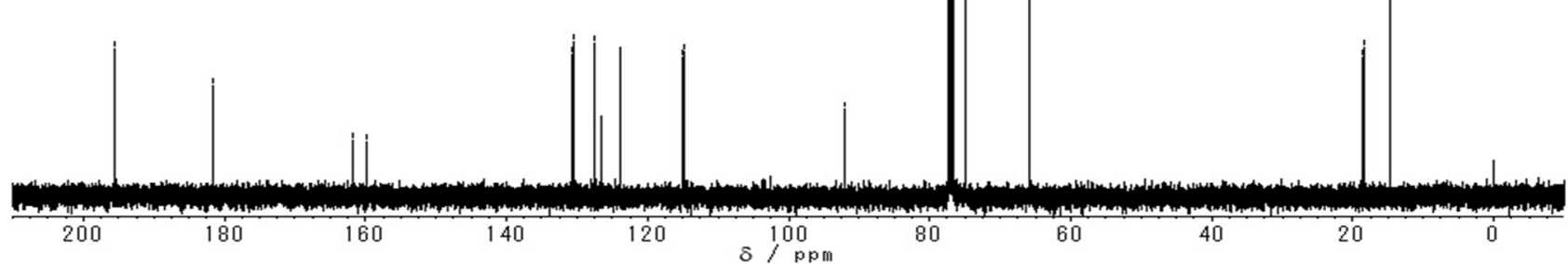




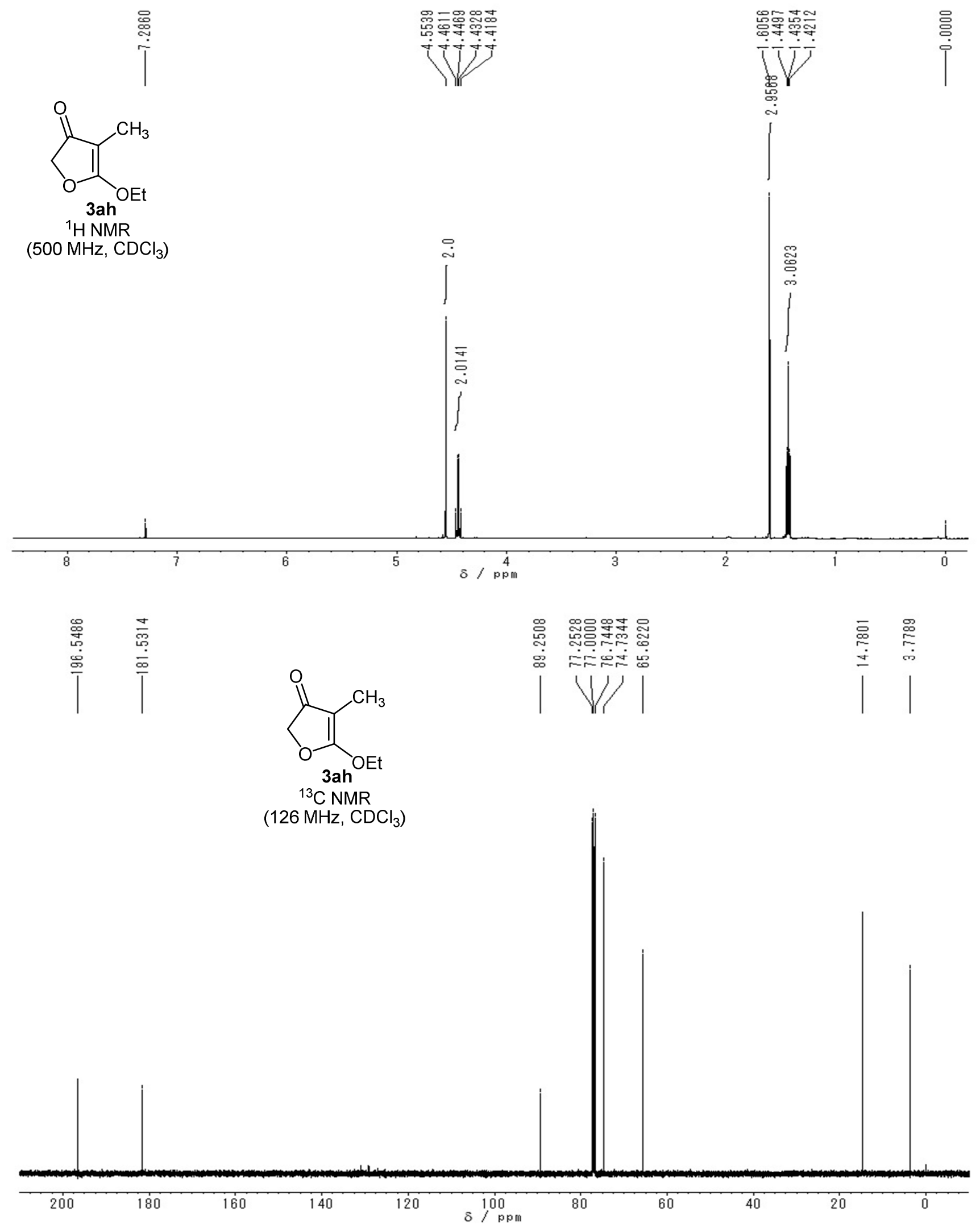



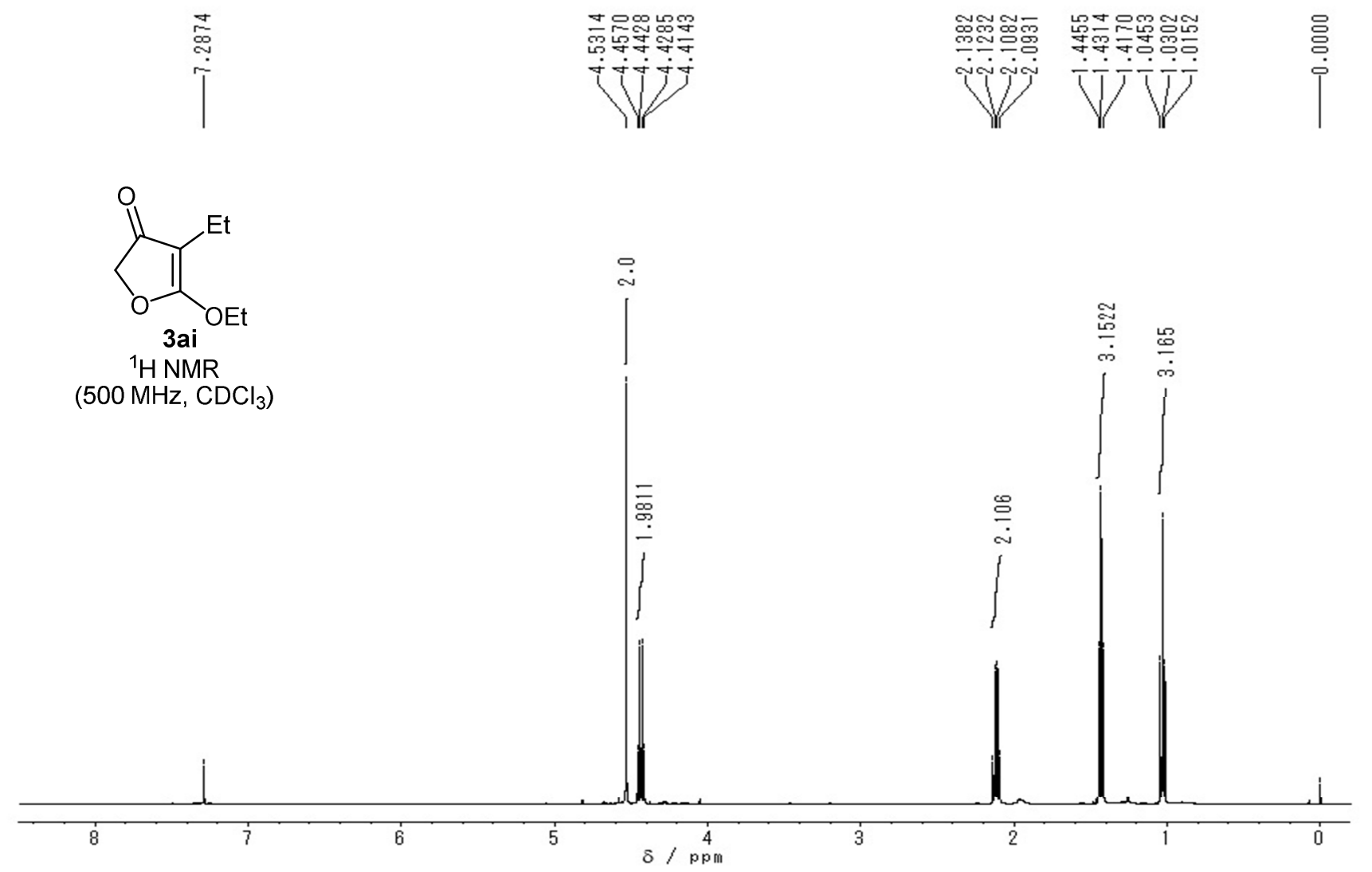

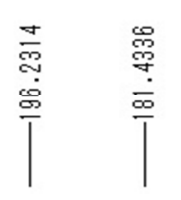

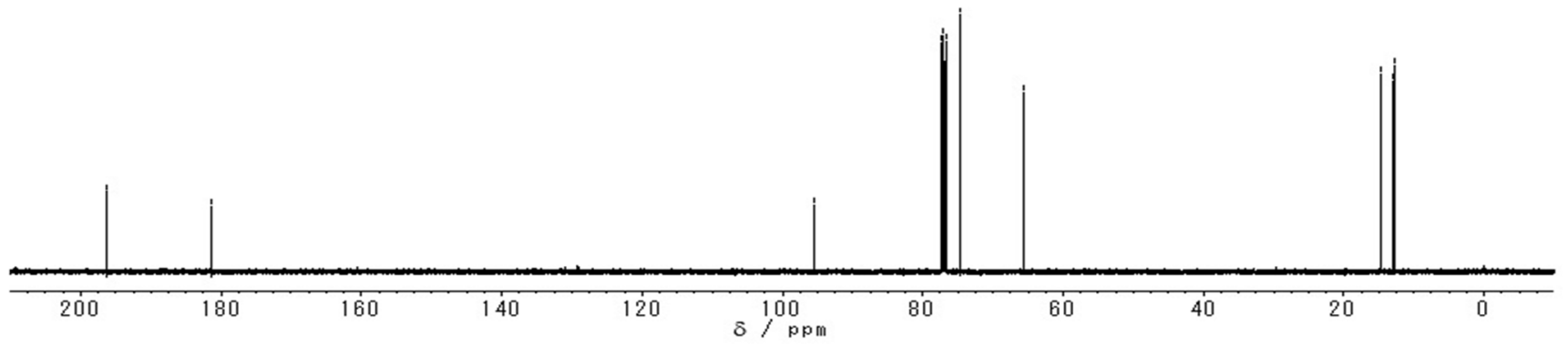




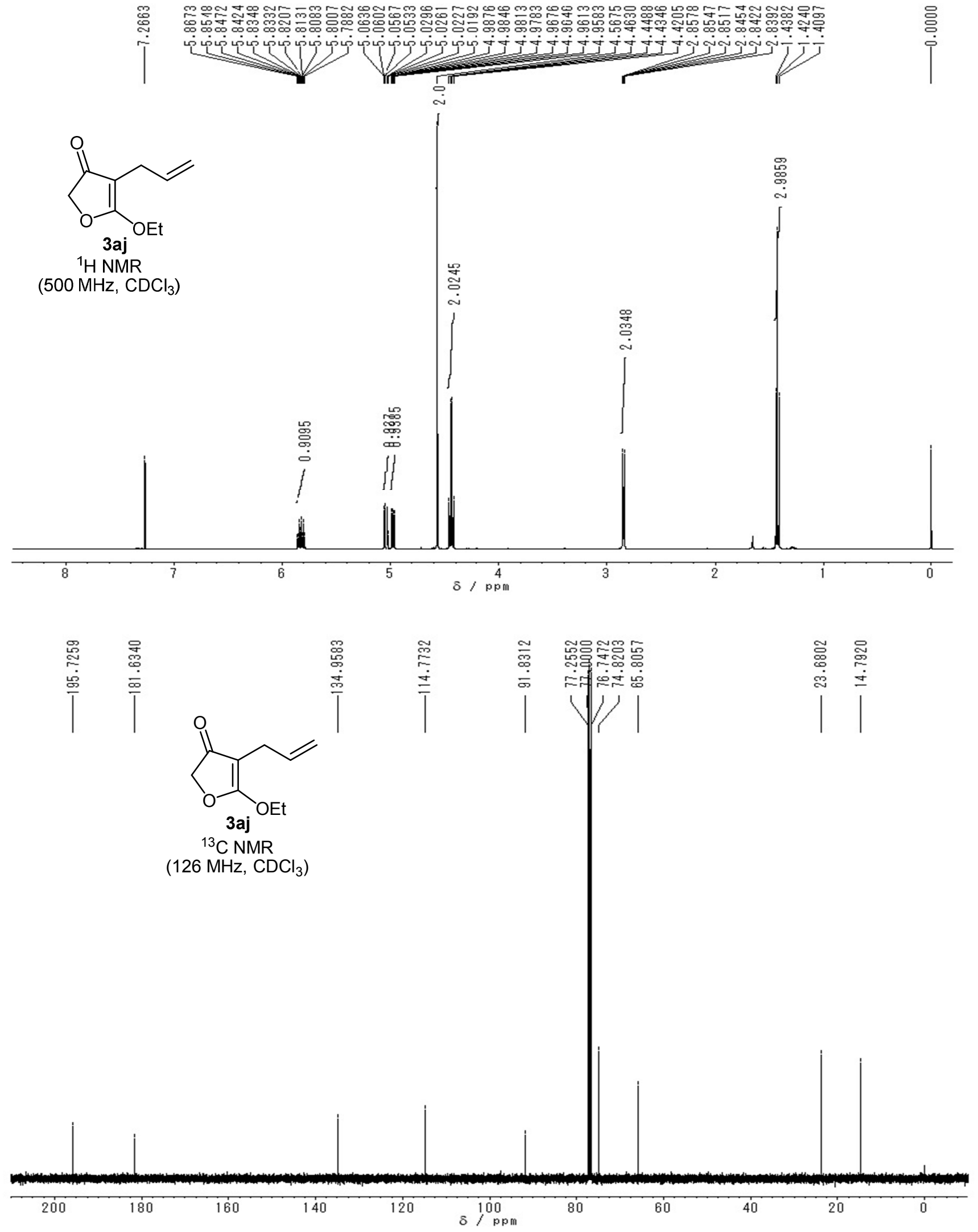

S38 


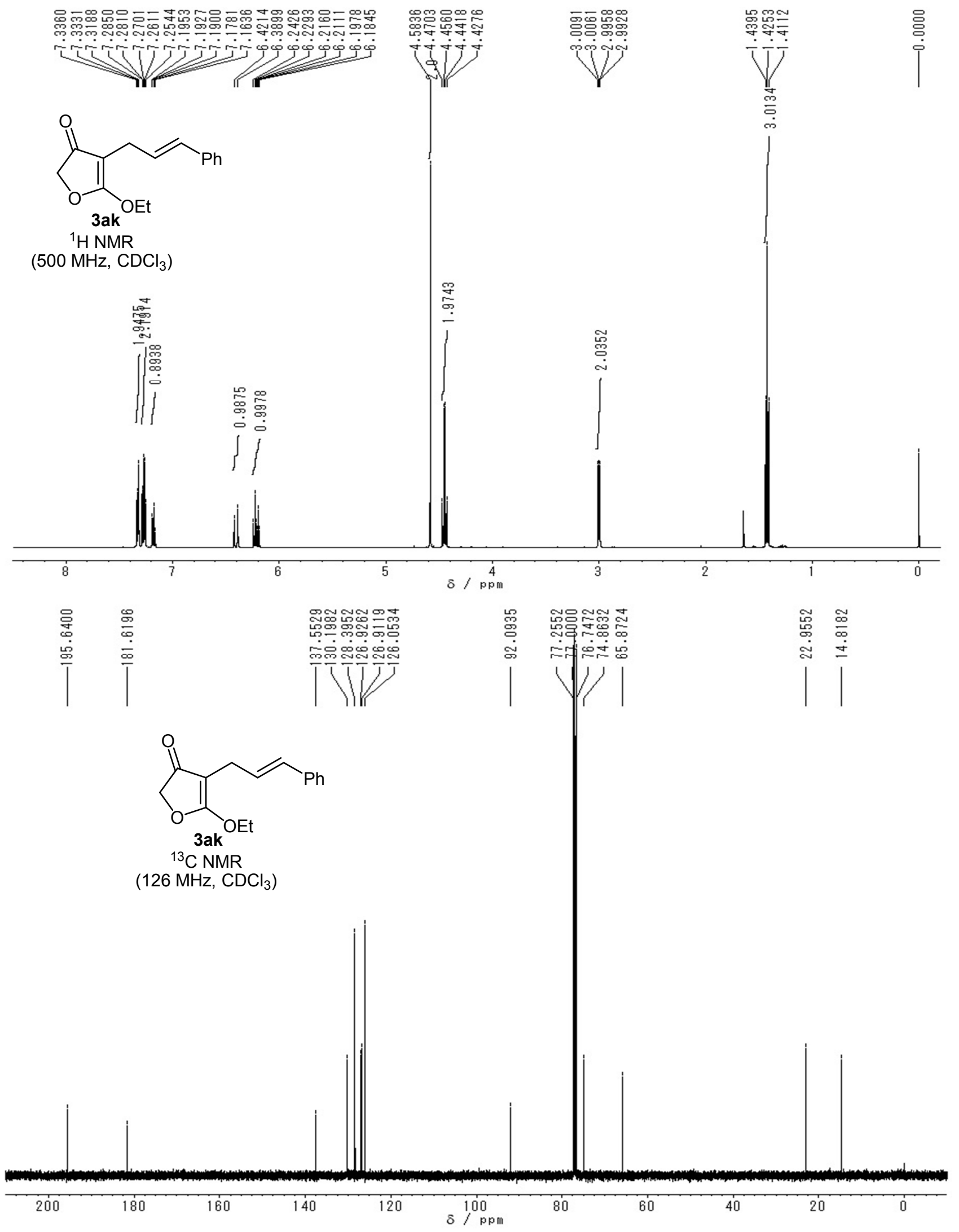




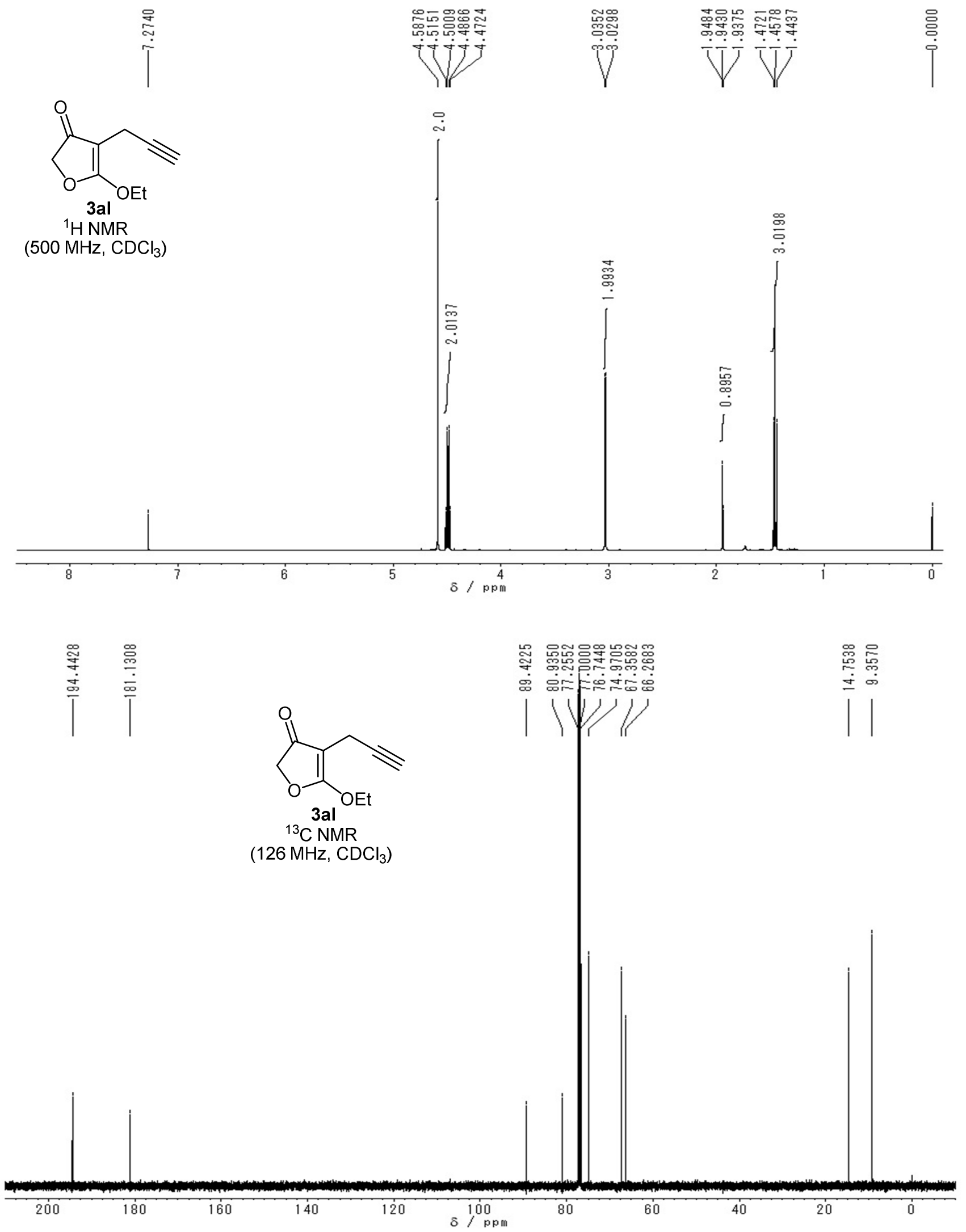




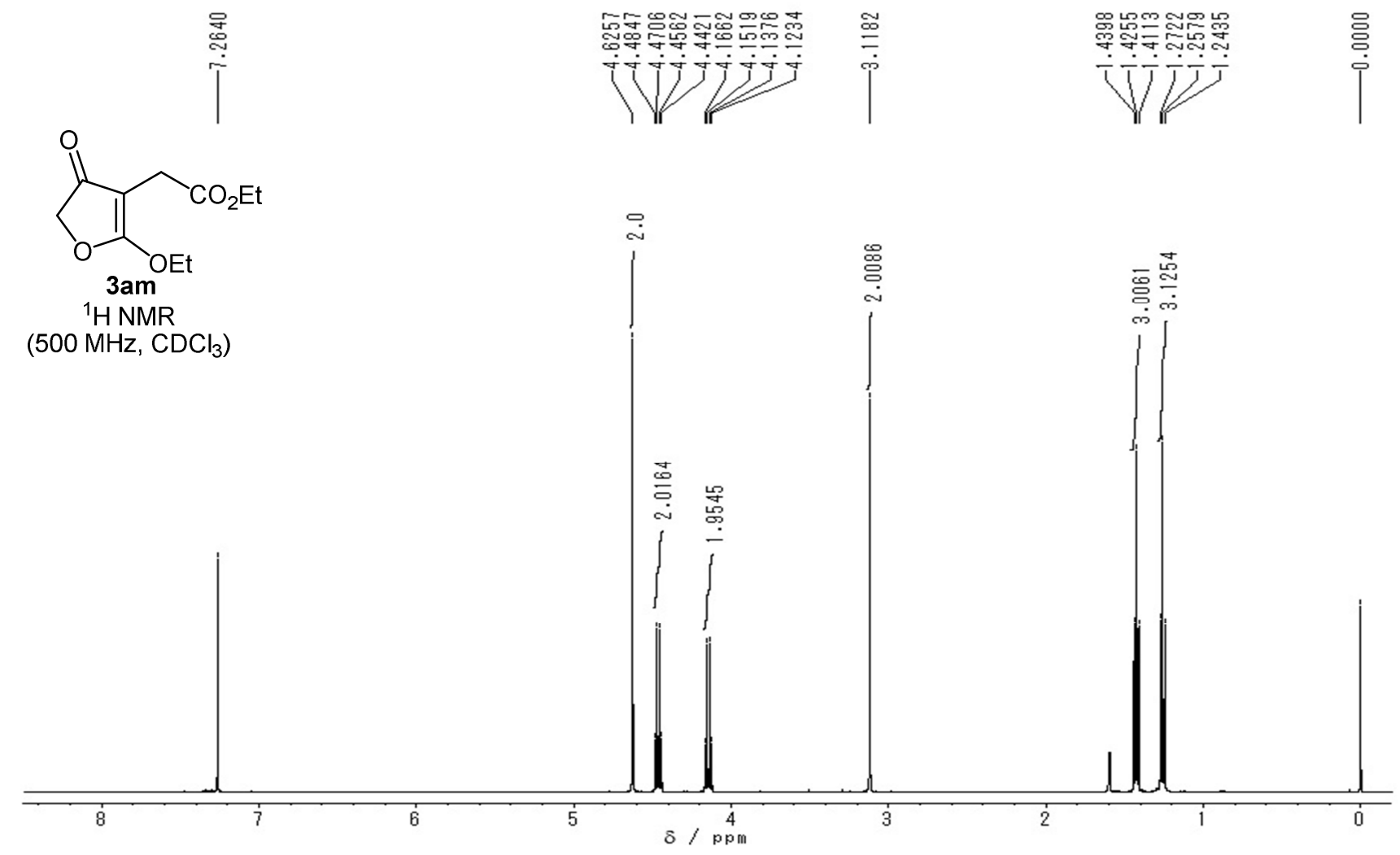

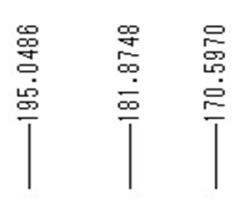

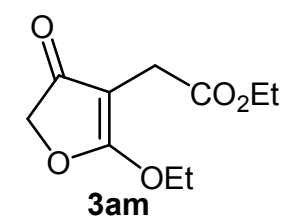

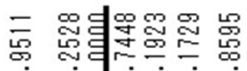

茄

票等息

${ }^{13} \mathrm{C}$ NMR

(126 $\mathrm{MHz} \mathrm{CDCl}_{3}$ )

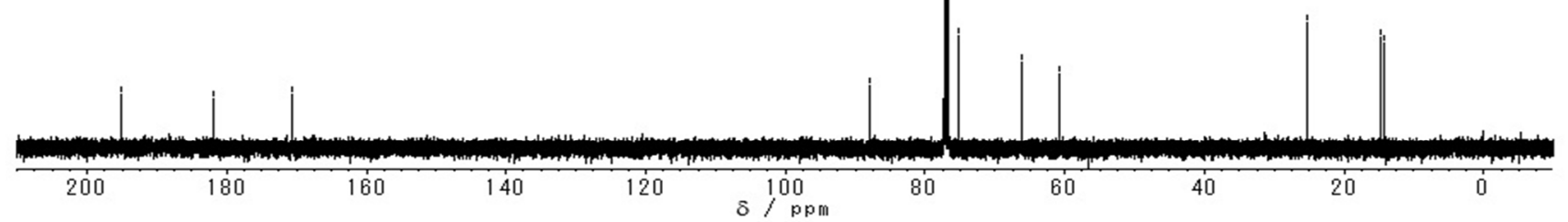




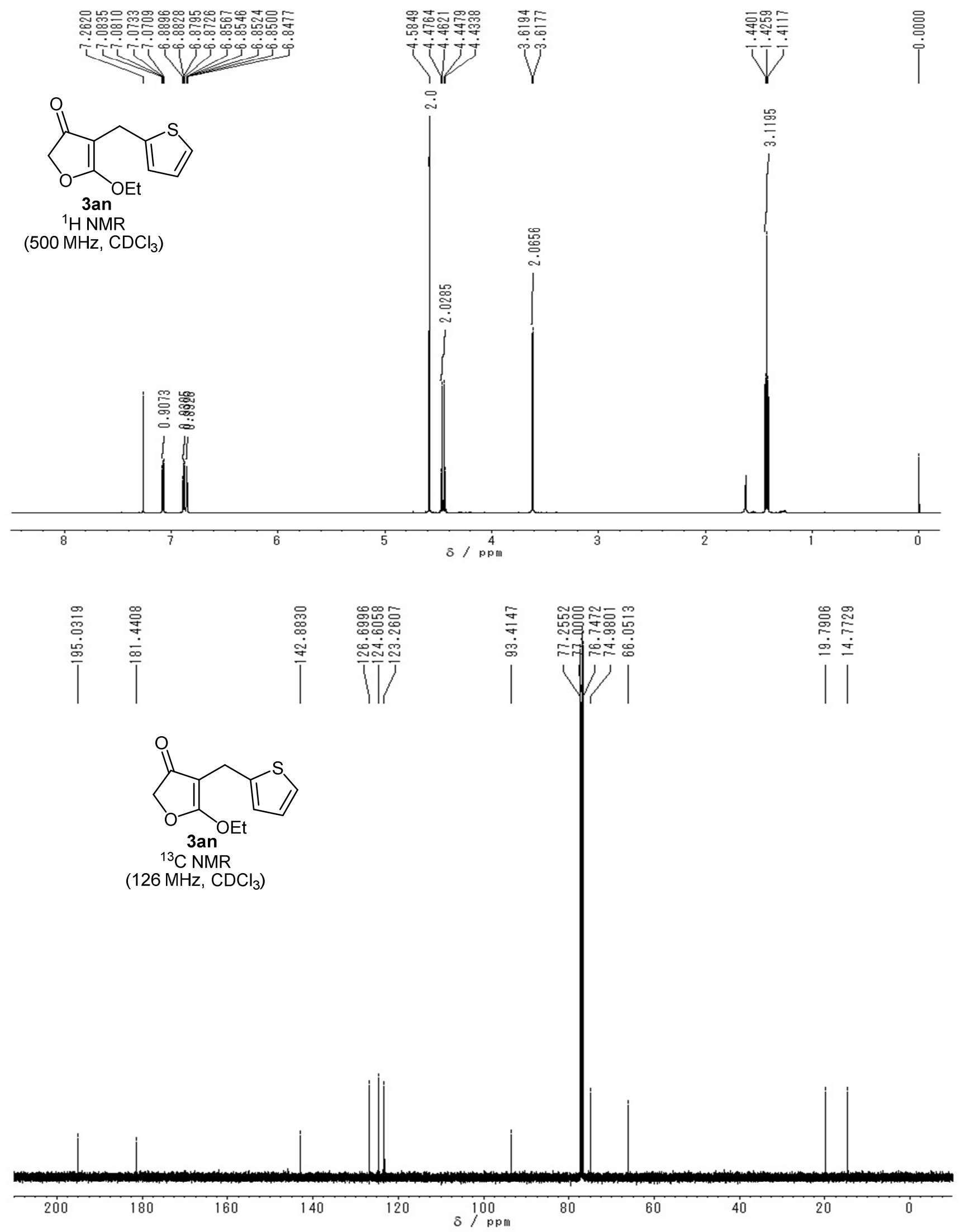




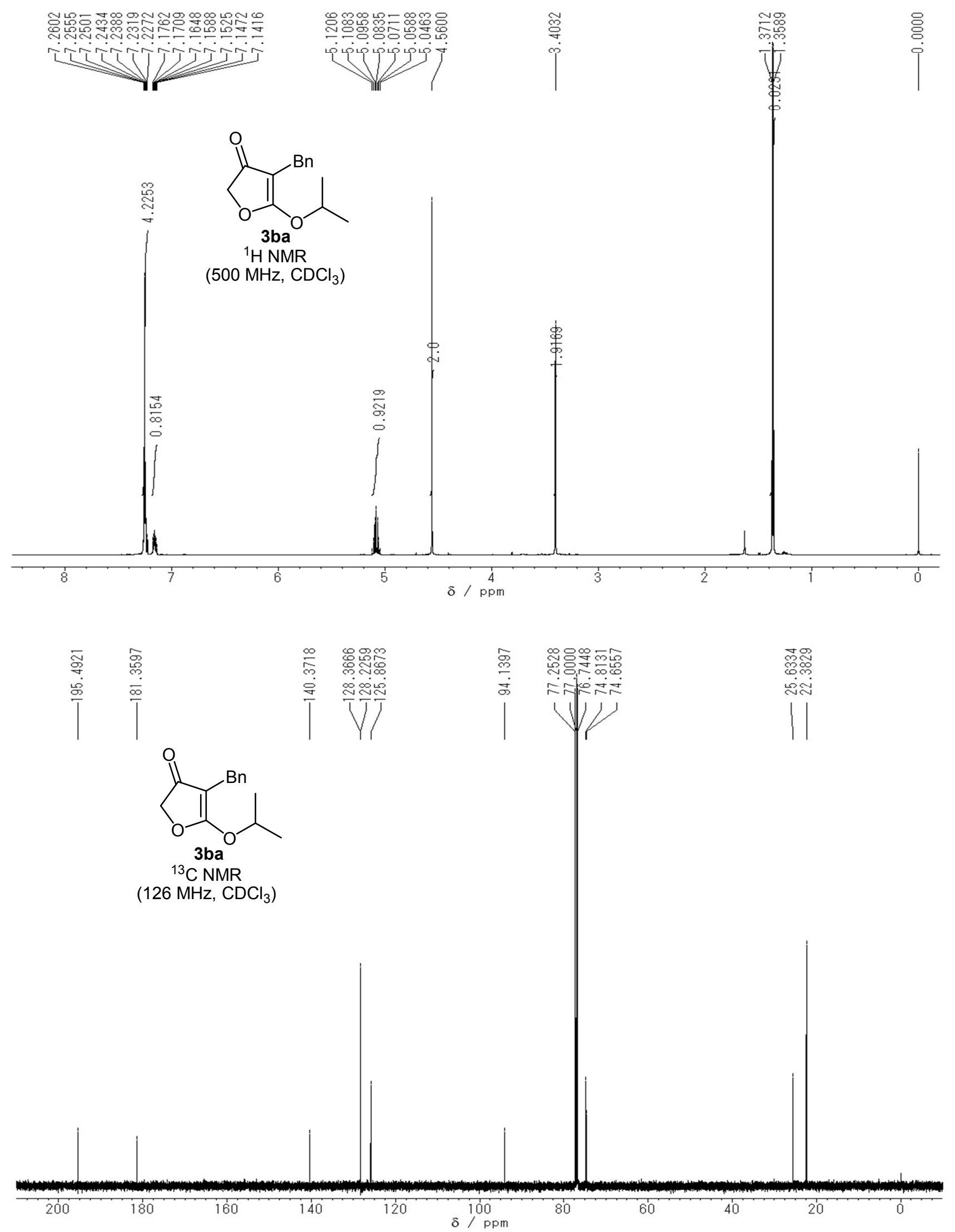

S43 


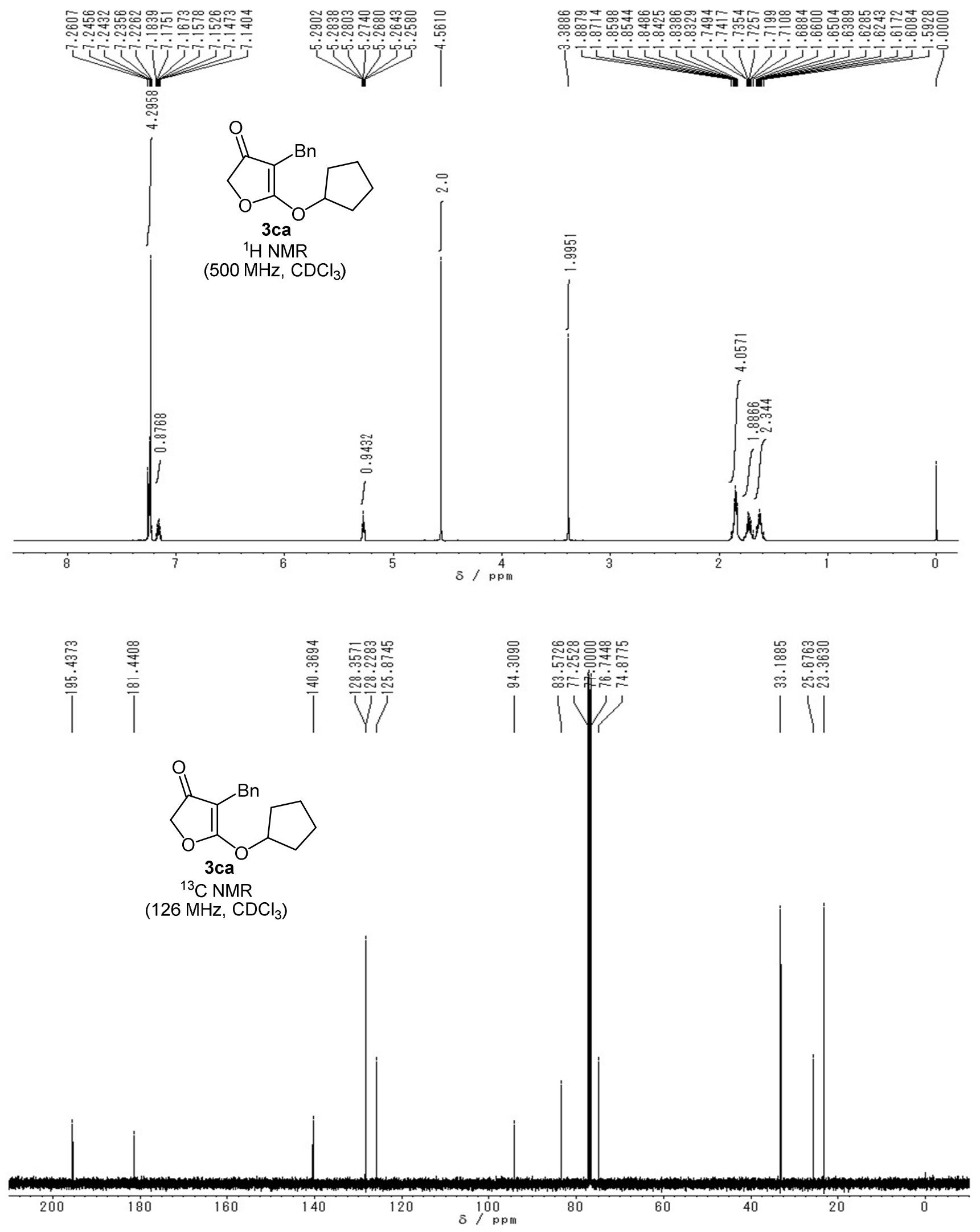




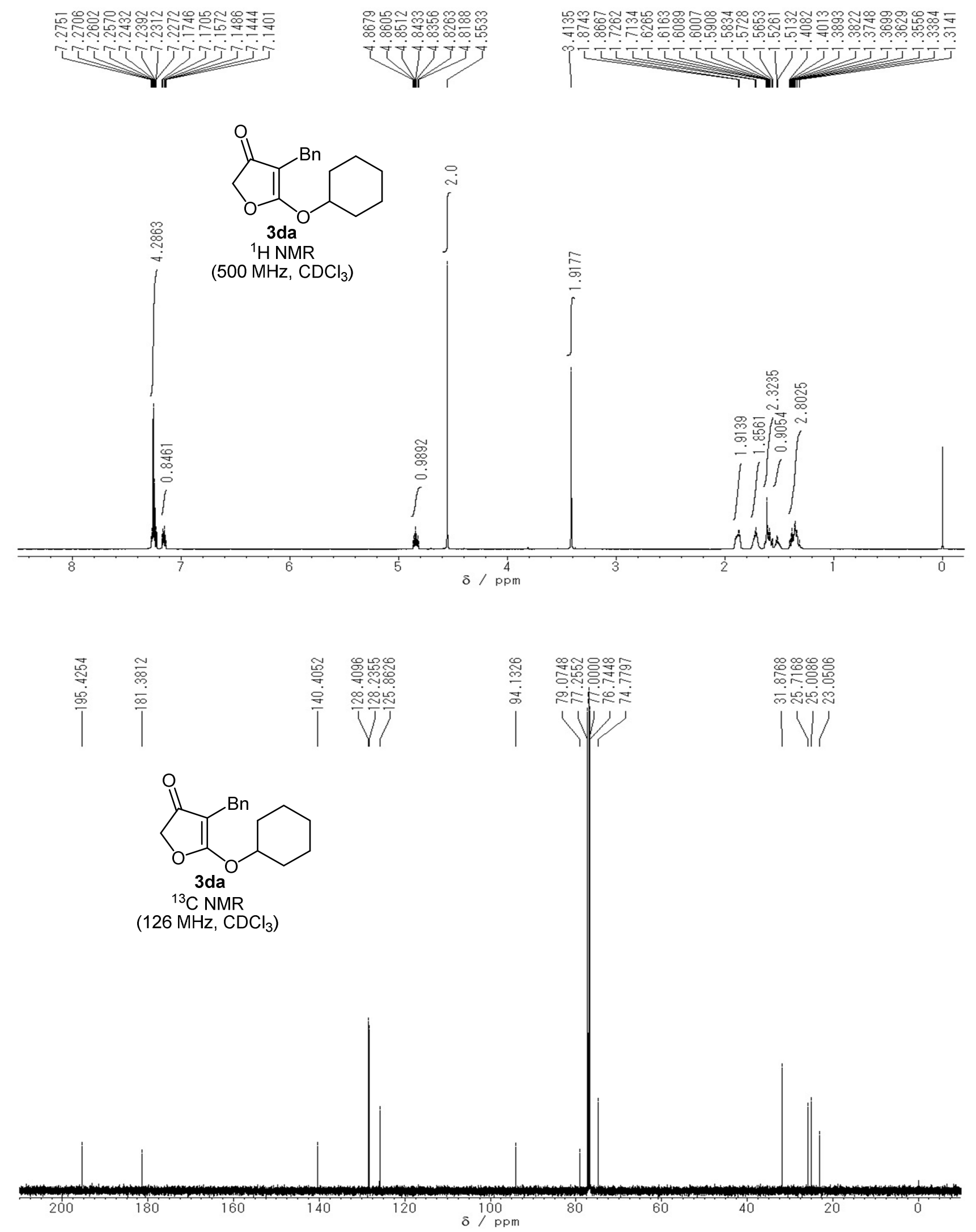



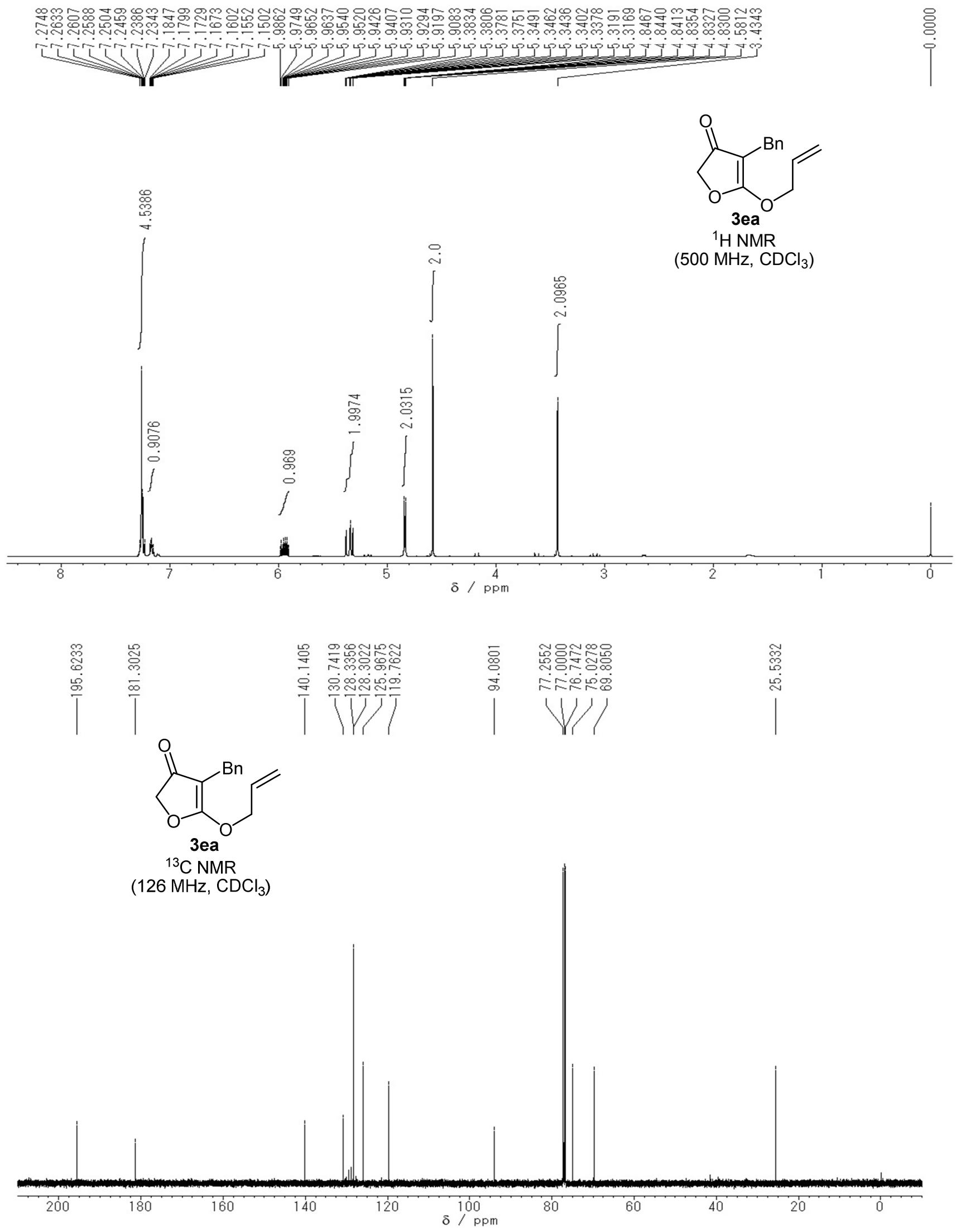

S46 


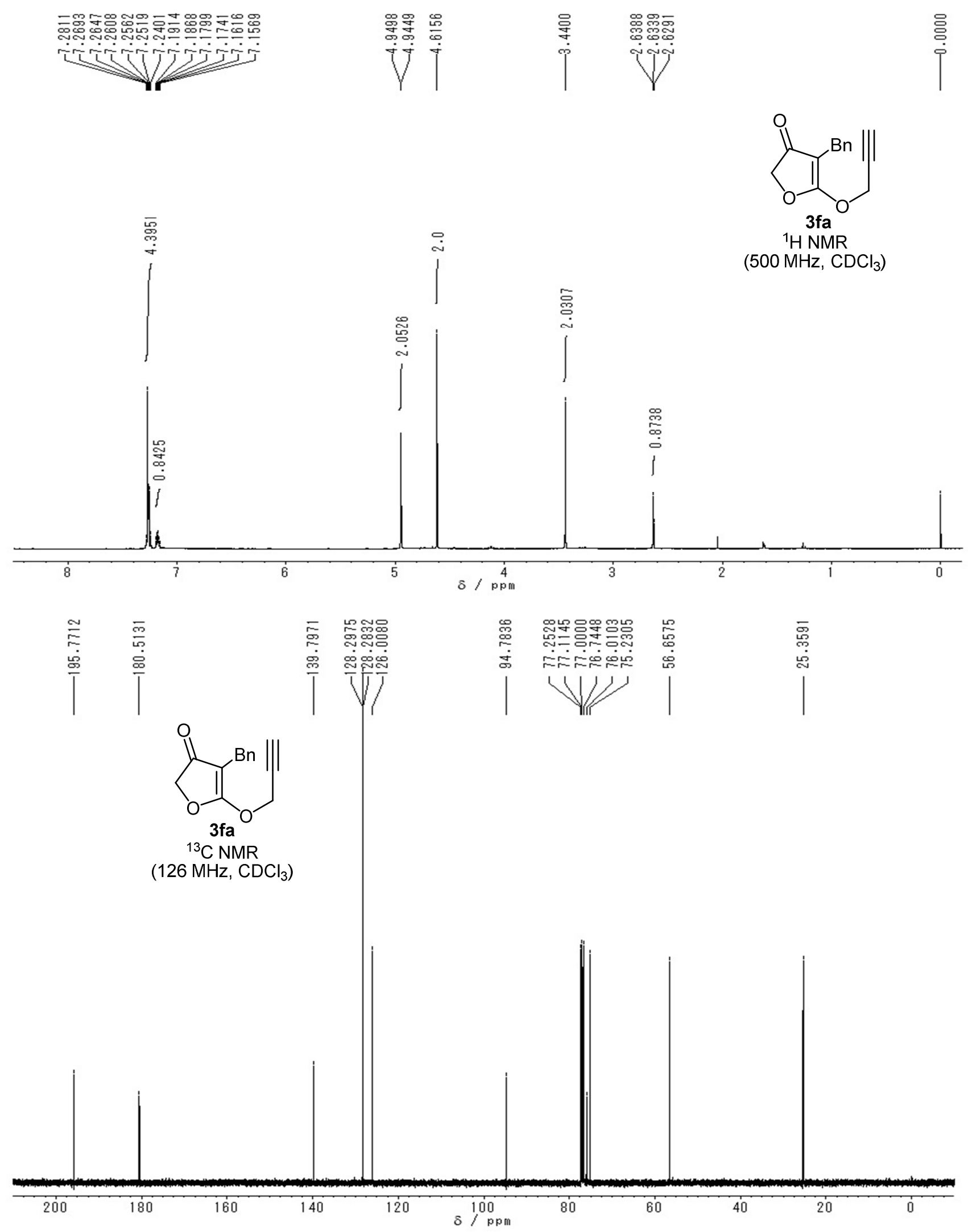




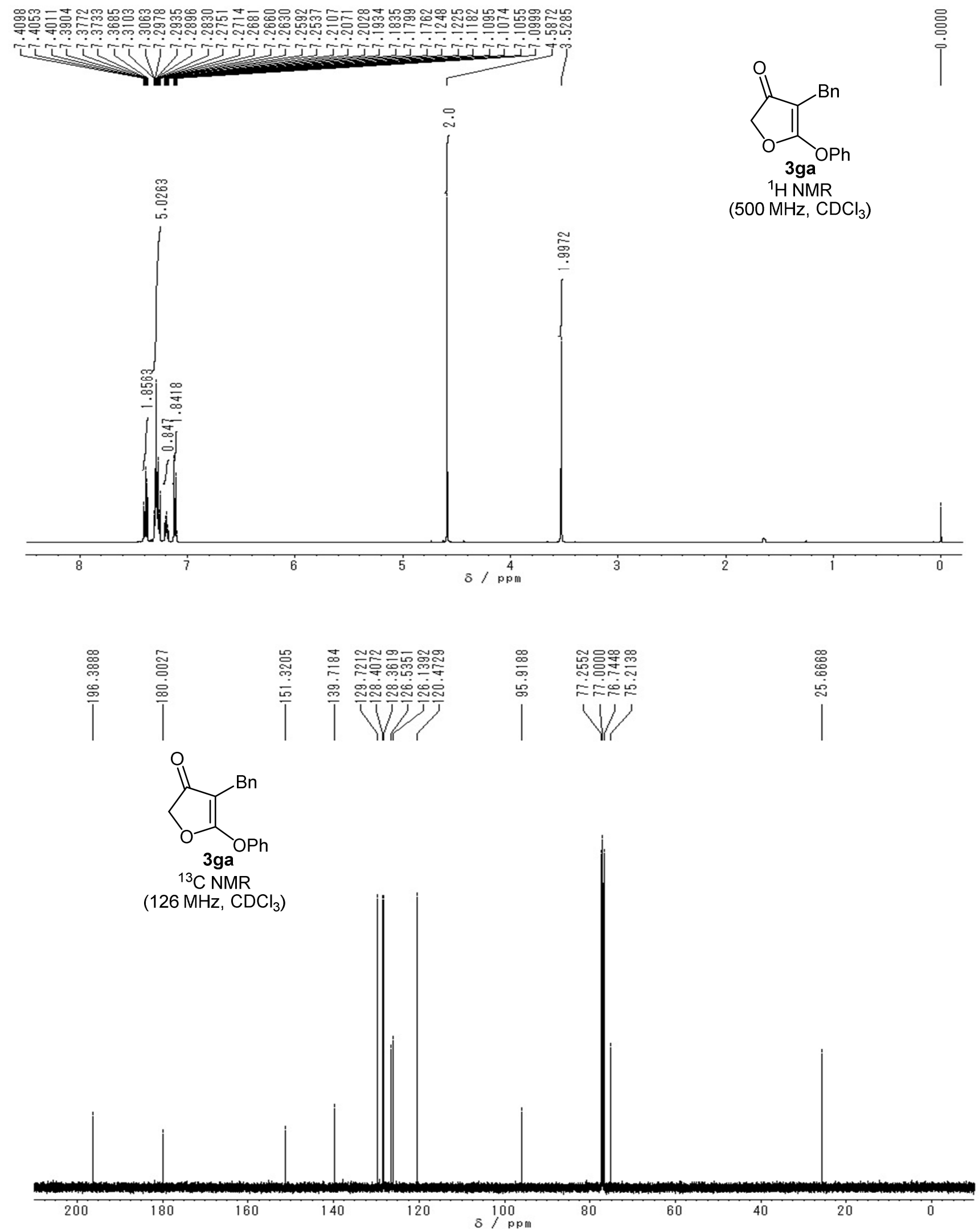




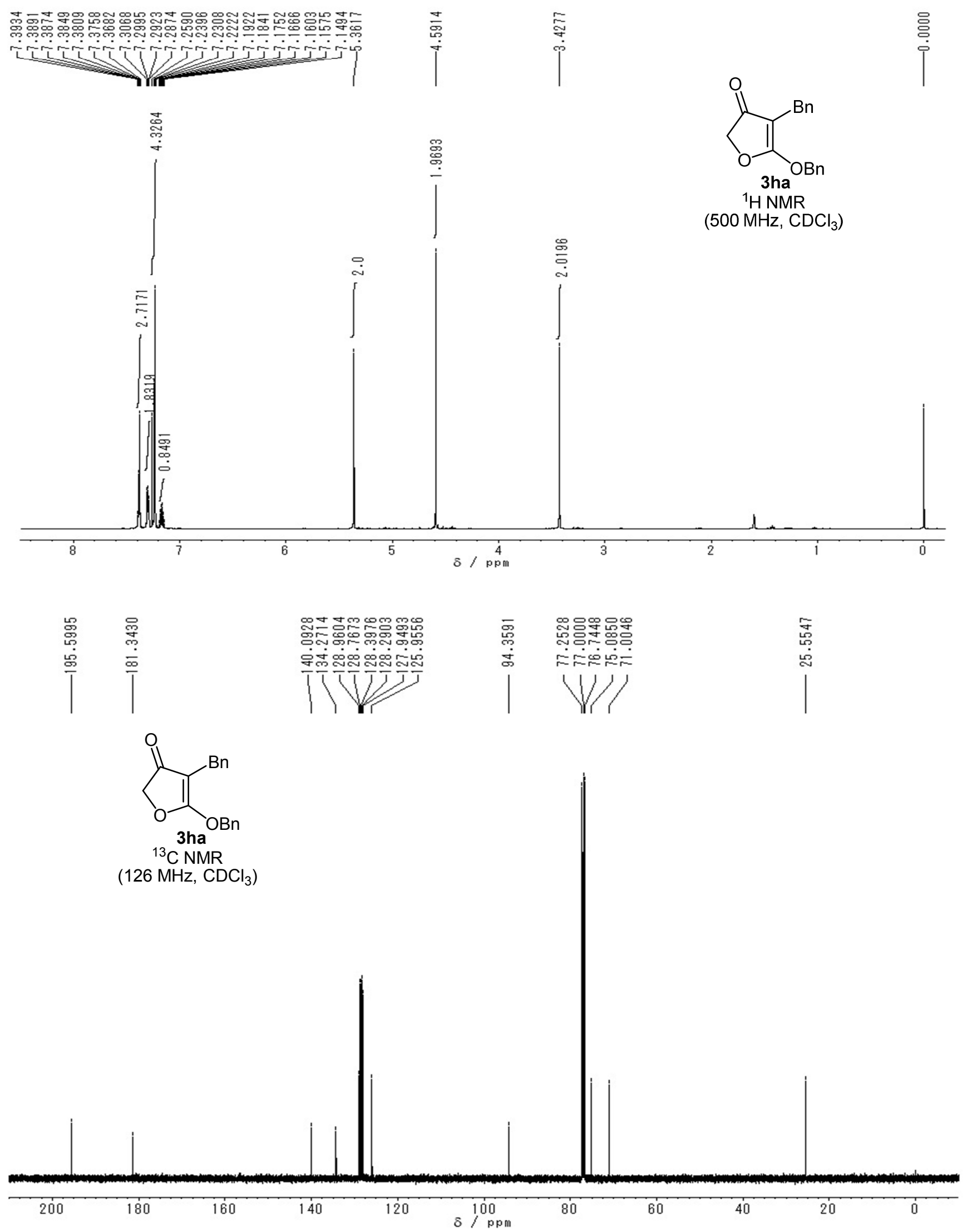

S49 

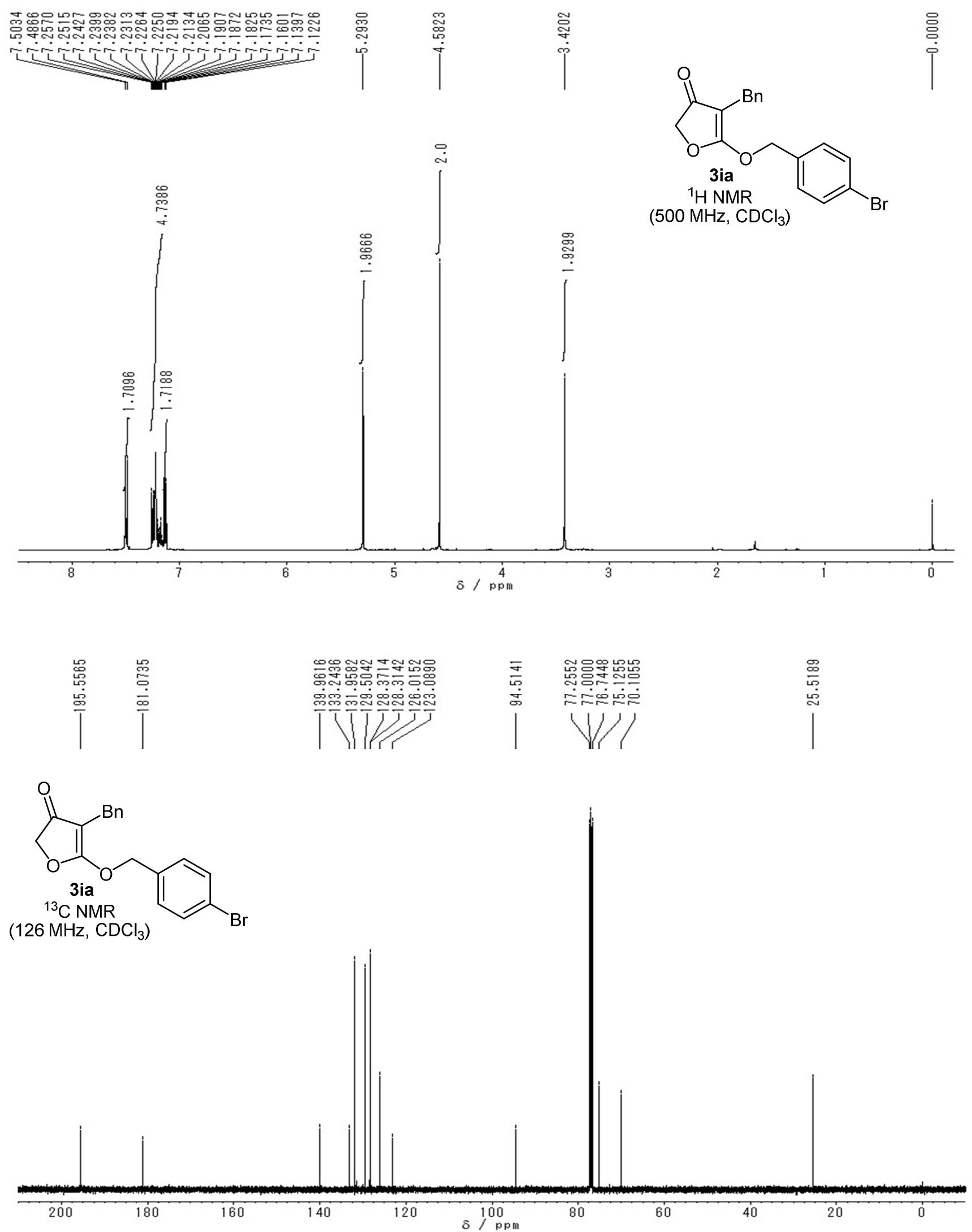

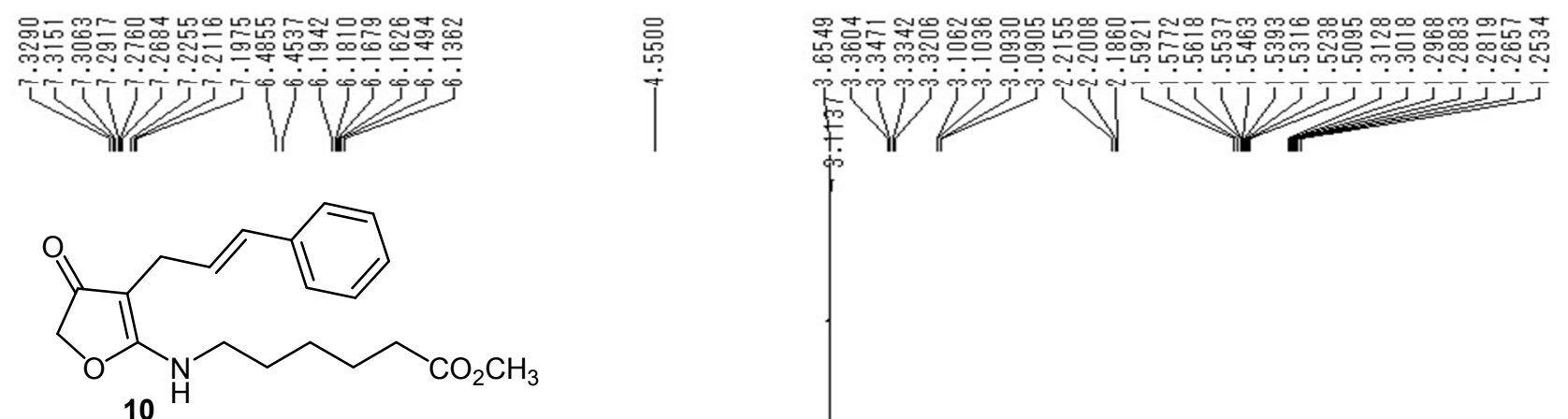

${ }^{1} \mathrm{H}$ NMR

(500 MHz, $\mathrm{CDCl}_{3}$ )
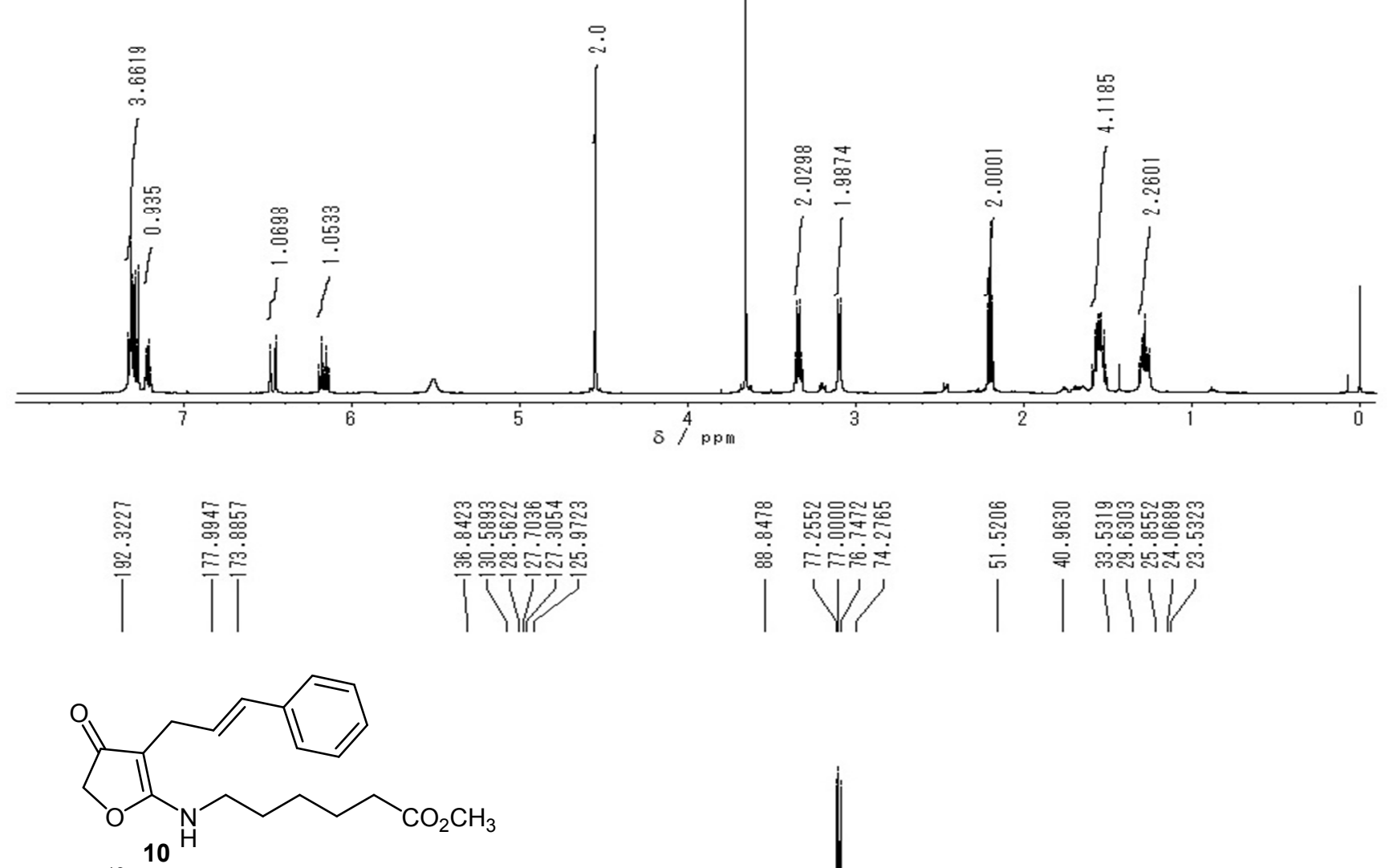

$\left(126 \mathrm{MHz}^{13} \mathrm{CDMCl}_{3}\right)$

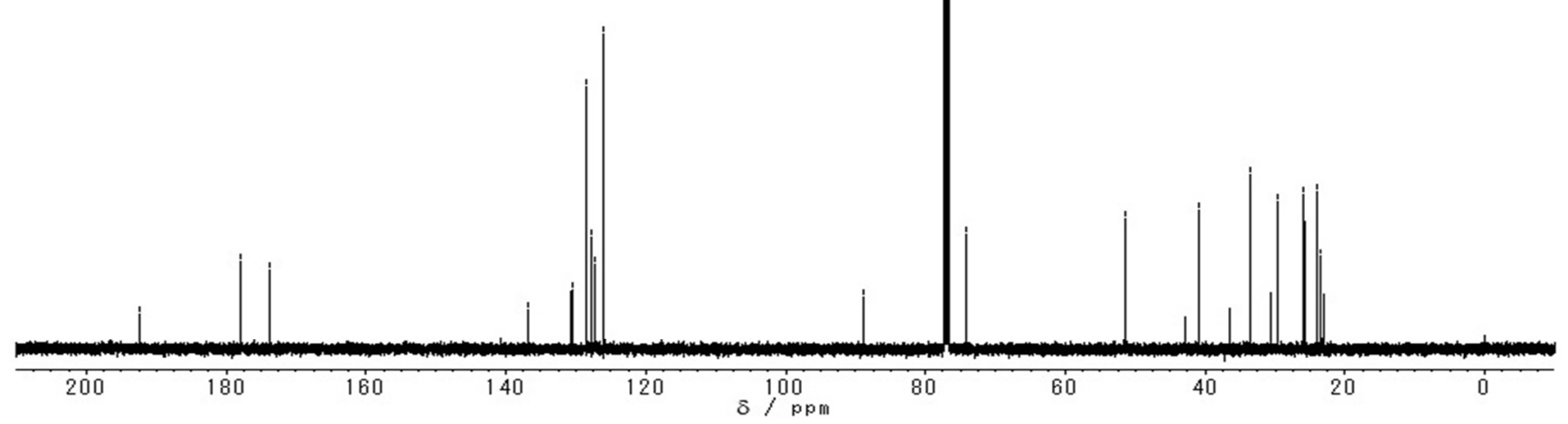

